\title{
Zgornje Radvanje, Cluster 10 - a Late Neolithic pit with a structure and smaller pits
}

\author{
Bine Kramberger \\ Maribor, SI \\ bine.kramberger@siol.net
}

\begin{abstract}
Many hollows defined as pit houses are known from the Neo-Eneolithic period. Similar pits were also detected at the Neo-Eneolithic settlement of Zgornje Radvanje. The cluster of pits presented in this paper shows a stratigraphic sequence. One of the phases yielded a structure. Pottery forms, production and decoration are presented for each individual phase. A comparison of pottery forms and decoration with other sites indicates that the earliest pottery assemblages originate from the late Neolithic period.
\end{abstract}

IZVLEČEK - Iz neo-eneolitskega obdobja so poznane številne jame, ki so opredeljene kot zemljanke. Podobne jame so bile odkrite tudi v neo-eneolitski naselbini Zgornje Radvanje. V kompleksu jam, $k i$ ga predstavljamo je bila odkrita stratigrafska sekvenca, $v$ kateri objekt predstavlja le eno izmed faz. Po posameznih fazah smo predstavili keramične oblike, tehnologijo izdelave keramike in ornament. Na podlagi primerjav oblik lončenine ter ornamentov z drugimi najdišči, smo keramične zbire najstarejših faz časovno umestili v obdobje poznega neolitika.

KEY WORDS - Neolithic, Eneolithic, northeastern Slovenia; settlement; pottery

\section{Introduction}

Radvanje, a quarter of the city of Maribor, is located on a plain which forms part of the Subpannonian Dravsko-Ptujsko polje (Ptuj-Drava field), located in close proximity to the Alpine foothills of Eastern Pohorje (Gams 1998.229-230, 236) (Fig. 1). Until recently, Radvanje was known as a Late Bronze Age, Hallstatt, Late La Tène, Late Roman (Teržan 1990. 26-36, 59-70), Roman and Early Medieval site (Strmčnik Gulič 1990; 1991; ک̌losar 2009), while only individual stone finds from the Neo-Eneolithic period were identified (Pahic 1972.30). In 2007, during the construction of the Maribor Western ring road, a multi-period site was discovered at Radvanje, location Zgornje Radvanje. A Neo-Eneolithic settlement covers most of this site. The site is still undergoing rescue excavation campaigns. ${ }^{1}$ The excavation at Zgornje Radvanje conducted during 2007 and 2008 yielded 35 structures, of which some 29 fall within the Neo-Eneolithic period and the others with- in the La Tène and Roman periods. In addition, two cremation graves and smaller pits dating to different periods were discovered (Koprivnik et al. 2009.1617). Some of the Neo-Eneolithic archaeological remains were damaged by water, which used to flow across one part of the site.

\section{Stratigraphic sequence of cluster 10}

This paper presents part of the Neo-Eneolithic settlement of Zgornje Radvanje. Six phases were identified within the deposit. Four are associated with the settlement, construction and destruction of the recognised structure and everyday activities. Two are related to water activity and are documented with a layer of alluvium and a palaeochannel. Phases were documented with a stratigraphic sequence and a Harris Matrix diagram (Fig. 2).

1 The excavation was, until the end of 2008, carried out by the Maribor Unit of the Institute for the Protection of Cultural Heritage (ZVKDS), under supervision of Mira Strmčnik Gulič. 


\section{Phase 1}

Phase 1 is the earliest phase of the settlement. It is documented with several pits (SE 323, 325, 327, $329,331,333,336$ ) cut into the bedrock (Fig. 3, App. 1,2). Their infill contained highly fragmented and burnt pieces of clay daub, pottery fragments and stone tools (Pl. 1.1 - Pl. 4.20).

\section{Phase 2}

Phase 2 is defined with the remains of a house. Its construction (posts) as well as destruction (fragments of burnt clay daub and a wooden structure) were documented (SE 271/272, 273/274, 343/344, 346/347, 348/349, -100/-101, -108/-109, 318). Everyday activities are noted with the remains of a hearth (SE 345) and clusters of pottery fragments and stone tools on the former walking surface (Fig. 4, App. 1, 2, Pl. 4.21 - Pl. 10.58). Several smaller pits were discovered adjacent to the house (SE 238/239, $267 / 268,269 / 270,275 / 276,277 / 278,680 / 681$ ).

\section{Phase 3}

Phase 3 is defined with a limited concentration (SE 279) of highly fragmented clay daub, charcoal and stone tools (Fig. 5, App. 2).

\section{Phase 4}

Phase 4 is shown as sludge alluvium (SE 232, Fig. 5, App. 1, 2). Randomly scattered fragments of Neolithic pottery and stone tools (Pl. 10.59 - Pl. 12.79) were found in the layer. The structure, dating to the La Tène period, was cut into the alluvium, and we therefore assume that the layer was deposited prior to this period (Fig. 6).

\section{Phase 5}

Phase 5 is defined with a palaeochannel (SE 234, 236) (Figs. 6, 7, Apps. 1, 2) with scattered fragments of Neolithic (Pl. 12.82), prehistoric (Pl. 12.81) and Early Medieval pottery (Pl. 12.80, 83).

\section{Phase 6}

The most recent part of the stratigraphic sequences of cluster 10 is represented by topsoil (SE 001, 002).

\section{Pottery assemblages}

A total of 1862 pottery fragments were found in cluster 10; most belong to Phase 2 (1042), followed by phases 4 (728), 1 (76) and 5 (16). No pottery was found in phase 3 .

Some 285 fragments of the total amount were typologically determined. The manufacturing technology

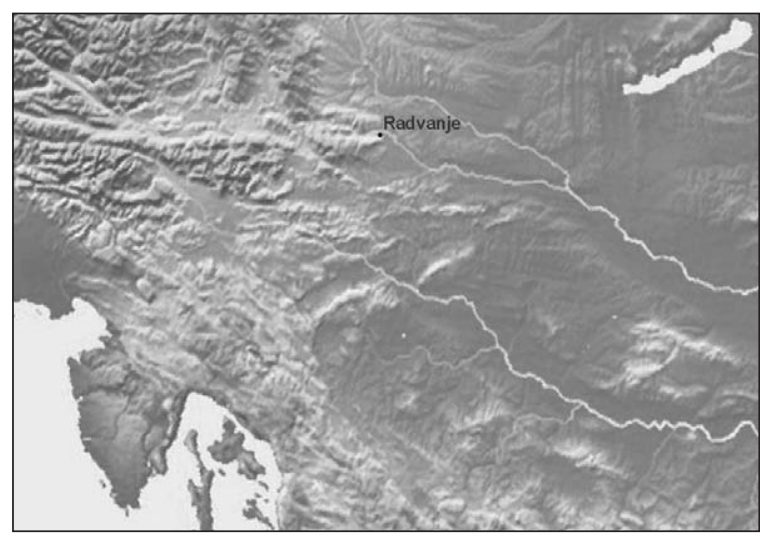

Fig. 1. Geographical location of Radvanje.

was defined with macroscopic standards (Horvat 1999; Tomaž 1997; 1999).

Twenty-one Neolithic (Figs. 8.LM01-21,9) and two Early Medieval fabrics (Fig. 8.LM22-23) were identified. They differ by type, size and frequency of inclusions. Quartz, mica and iron oxides were the most commonly used inclusions and were present in all fabrics. Organic material and an unidentified white material are rarer. Calcium carbonate is present only in the Early Medieval fabric (Fig. 8).

For the purposes of the macroscopic analysis, we also considered differences in the granularity of fabrics, surface treatment before firing, firing technique, hardness of pottery and pottery decoration techniques.

The typologically determined pottery assemblage consists of bowls, dishes, footed bowls/dishes, two miniature bowls and dishes, a miniature footed bowl/dish, a pitcher, a pot, a ladle, a spoon, a lid and an oil lamp. The remainder of the assemblage was defined as fragments of bases, applied decoration, handles, lugs and spouting nozzles.

\section{Phase 1}

The Phase 1 pottery was made of eight different fabrics. Fine-grained fabric prevails (74.1\%) (Fig. 18), with the most common fabrics being LM09 (29.6\%) and LM12 (25.9\%). LM01 (18.5\%) and LM08 (11.1\%) were less frequent. LM06 (Pl. 4.19 wall of a pot), LM11 (pot Pl. 3.13), LM16 (Pl. 2.10 wall fragment) and LM18 (Figs. 9 and 17) are rare.

The sponging of pottery before firing is common (88.9\%). Burnishing is less frequent (Fig. 19), while coloured clay slip (Pls. 1.1, 4.19) is rare. 


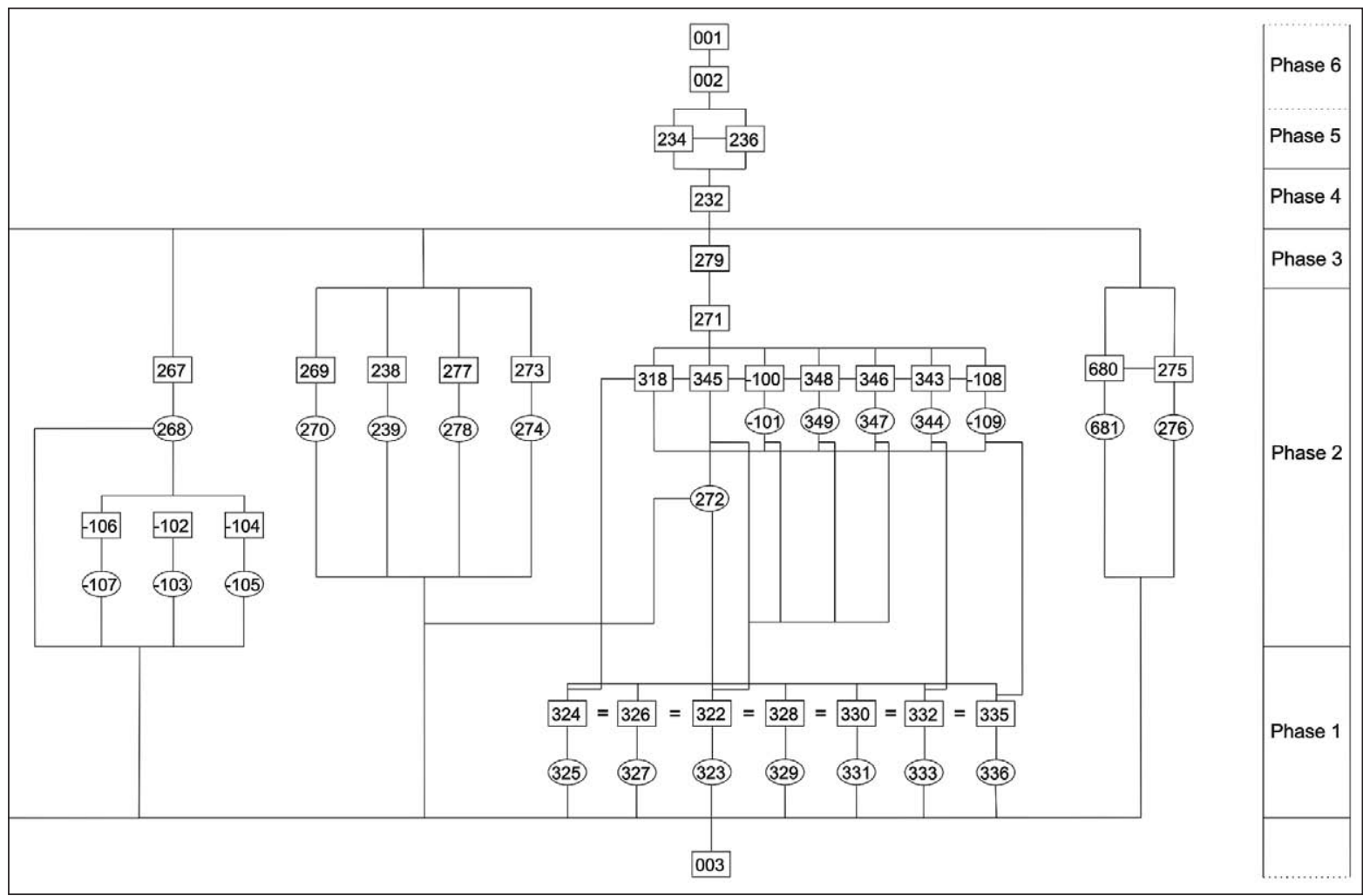

Fig. 2. Cluster 10, the stratigraphic sequence.

Firing under incomplete oxidising conditions is most common in Phase 1 (59.3\%). This is followed by firing under oxidising conditions (14.8\%); reducing conditions with oxidising conditions used at the end of the firing process (11.1\%); incomplete oxidising conditions with reducing conditions at the end of the firing process (7.4\%); and oxidising conditions with reducing conditions at the end of the firing process $(7.4 \%)$ (Fig. 20).

Most of the Phase 1 pottery is very hard (7, 8 and 9 on Mohs' scale of hardness) (63\%). Hard pottery (3 and 4 on Mohs' scale of hardness) $(22.2 \%)$ and very hard pottery (5 and 6 on Mohs' scale of hardness) (14.8\%) are less frequent (Fig. 21).

Some $27.33 \%$ of the Phase 1 pottery was decorated with grooving (motifs Fig. 10f, g), $27.33 \%$ with awl impressions (motifs Fig. 10a, e) and $27.33 \%$ with handmade applied decoration (motifs Fig. 10b-d). Only one fragment carries a combination of handmade applied decoration and channelled decoration (motif Fig. 10h), and another one a combination of handmade applied decoration, channelled decoration and awl impressions (motif Fig. 10i) (see also Fig. 22).

The pottery assemblage contains 27 fragments, which were typologically determined as pots (55.6\%) (Fig. 11g-n, Pl. 2.9, Pl. 2.11, 12, Pl. 3.13 - Pl. 4.20), bowls (18.5\%) (Fig. 11a-c, Pls. 1.3, 4, 1.6, 7), dishes $7.4 \%$ (Fig. 11d-e, Pl. 1.5, 8) and dishes or bowls (3.7\%) (Fig. 11f, Pl. 1.1). The remaining $14.8 \%$ of the pottery finds do not fall within these categories $(e . g$. Pls. 1.2, 2.10) (Fig. 23).

\section{Phase 2}

The Phase 2 pottery was manufactured from 15 different fabrics. Very fine-grained fabric is most common (41.7\%), followed by fine- $(35.2 \%)$, medium(23.5\%) and coarse-grained fabric (0.6\%) (Fig. 18). The most frequently used fabrics are LM01 (35.8\%) and LM08 (25.3\%), followed by LM18 (11.7\%), LM07 (6.8\%) and LM16 (6.2\%). LM02-LM05, LM12, LM13, LM17, LM19, LM21 are rare (Figs. 9 and 17).

Some $89.9 \%$ of pottery was sponged before firing. Burnishing and smoothing are less frequent (Fig. 19). Some $4 \%$ of pottery shows sponging with an additional coloured clay slip (Pls. 9.55, 8.51, 9.54).

Firing under incomplete oxidising conditions prevails (46.6\%), followed by oxidising conditions with reducing conditions at the end of the firing process (20.5\%), incomplete oxidising conditions with redu- 


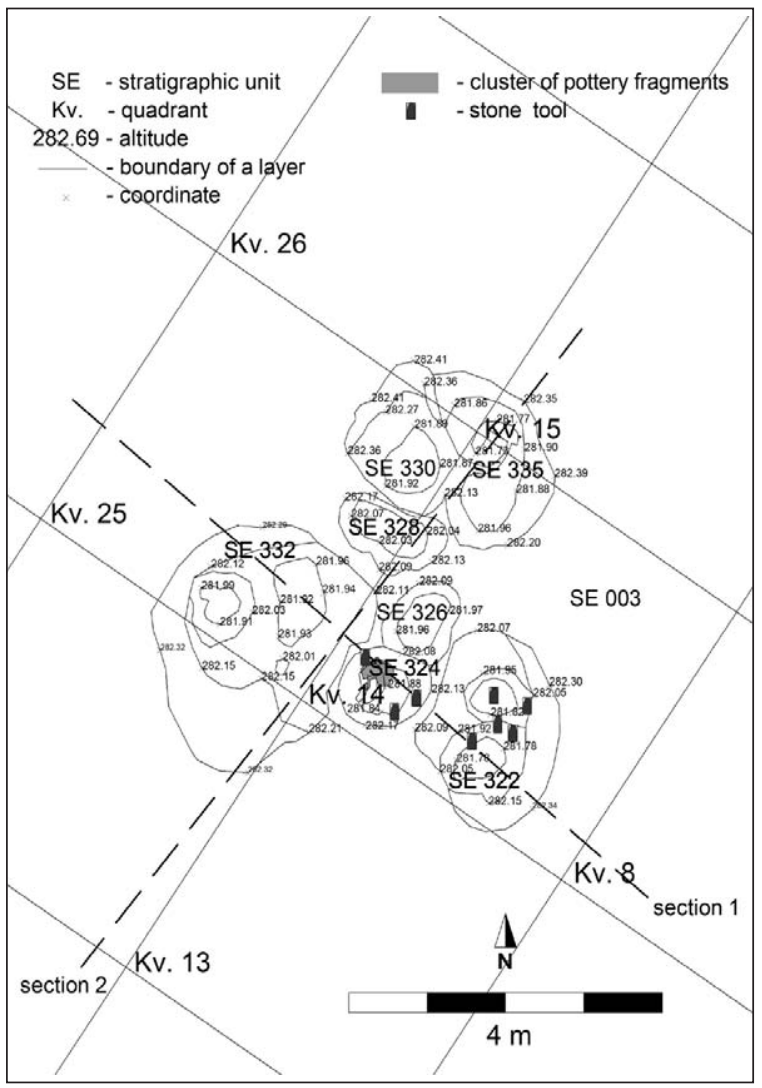

Fig. 3. Plan. Phase 1.

cing conditions at the end of the firing process $(11.8 \%)$, oxidising conditions $(9.9 \%)$, reducing conditions with oxidising conditions at the end of the firing process $(7.5 \%)$ and reducing conditions $(3.7 \%)$ (Fig. 20).

Most of the Phase 2 pottery is hard ( 3 and 4 on Mohs' scale of hardness) (49.4\%). Very hard (5 and 6 on Mohs' scale of hardness) (36.4\%) and extremely hard pottery (7, 8 and 9 according to Mohs' scale of hardness) (14.2\%) are less common (Fig. 21).

As far as decoration is concerned, grooving (48.2\%) and channelled decoration (22.2\%) prevail (motifs Fig. 12d-f, h-i, k-n). These are followed by applied decoration (12.9\%) (motifs Fig. 12b, c), awl impressions (1.9\%), a combination of grooving and awl impressions (7.3\%) (motifs Fig. 12g, j), a combination of grooving and handmade applied decoration $(1.9 \%)$ (motif Fig. 120) and a combination of channelled decoration and awl impressions (5.6\%) (motif Fig. 12a) (see also Fig. 22).

The pottery assemblage comprises 162 fragments which were typologically determined as pots (29\%) (Fig. 13s-y, Pl. 7.46 - Pl. 9.52, Pls. 9.55, 10.58), bowls (9.3\%) (Fig. 13a, c-i, Pl. 4.22 - Pls. 5.31, 6.34,

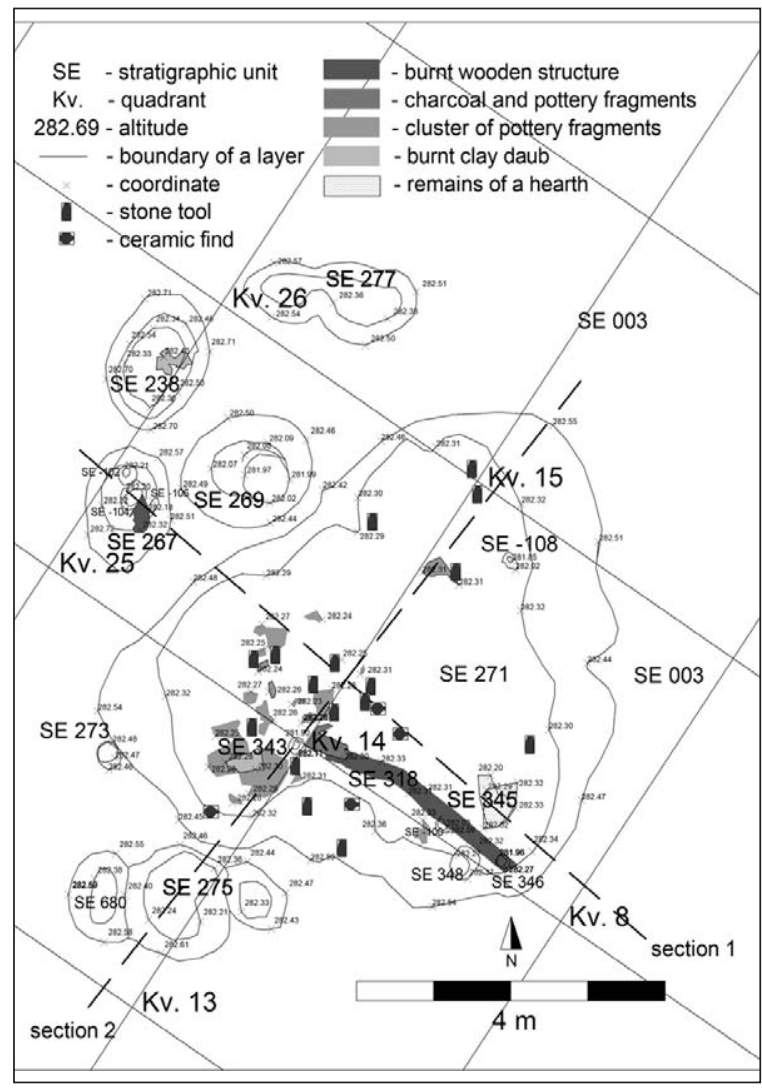

Fig. 4. Plan. Phase 2.

35, 10.57), pitchers (8.6\%) (Fig. 13q-r, Pl. 7.41-45), dishes (6.2\%) (Fig. 13j-p, Pl. 6.32, 33, 36, 37, 39, 40 ), dishes or bowls (4.9\%) (Pl. 4.21), and pitchers or bowls (4.3\%). Other forms are less frequent (37.7\%). We recognised a miniature cup (Fig. 13b) (Pl. 6.38), ladles (Pl. 9.53, 54), fragments of handles, lugs, applied decoration, spouting nozzles, and a special find that can be interpreted as a lamp (Pl. 9.56) (Fig. 23).

The lamp was well fired in oxidising conditions and falls within the category of the hardest pottery $(7,8$ and 9 on Mohs' scale of hardness). It has a solid handle and a nozzle on its opposite side. The base is flat. Traces of secondary burning can be seen on both, the internal and the external side of the spout (Fig. 14).

\section{Phase 4}

The phase 4 pottery was made of fourteen different fabrics. Most fabrics are very fine-grained (47.8\%), followed by fine- $(29.3 \%)$, medium- $(20.7 \%)$ and coarse-grained (2.2\%) (Fig. 18.). The most common fabrics are LM01 (44.6\%) and LM08 (21.7\%), followed by LM18 (6.5\%) and LM07 (5.4\%). LM03, LM10, LM13-17 LM19-21 are rare (Figs. 9 and 17). 


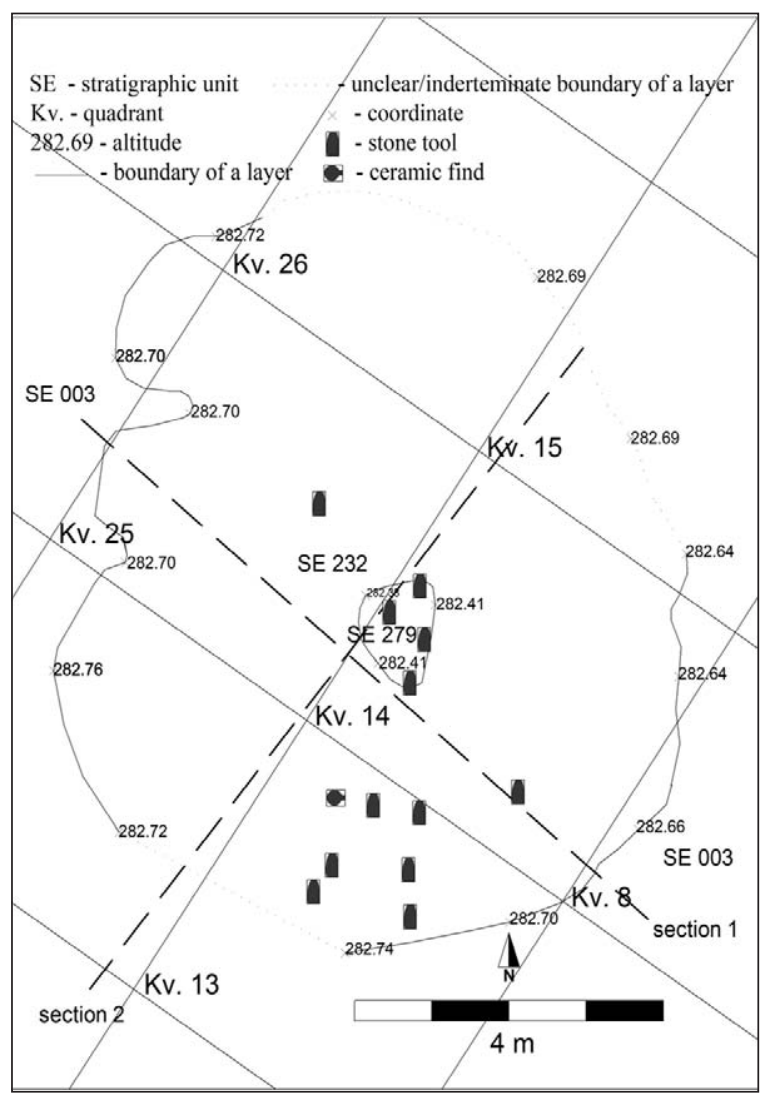

Fig. 5. Plan. Phases 4 and 3.

Sponging of pottery before firing prevails (93.2\%), followed by burnishing and smoothing (Fig. 19). Clay slip is rare $(1.4 \%)$.

Firing under incomplete oxidising conditions was used most often (46.1\%), followed by incomplete oxidising conditions with reducing conditions at the end of the firing process (25.3\%), oxidising conditions with reducing conditions at the end of the firing process (14.3\%), reducing conditions $(6.6 \%)$, oxidising conditions (4.4\%) and reducing conditions with oxidising conditions at the end of the firing process (3.3\%) (Fig. 20).

Most of the pottery is hard ( 3 and 4 on the Mohs' scale) $(51.6 \%)$, followed by very hard ( 5 and 6 on the Mohs' scale) (36.3\%) and extremely hard pottery (7, 8 and 9 on the Mohs' scale) (12.1\%) (Fig. 21).

Grooving (32.6\%) and channelled decoration (38.2\%) are the most common decoration techniques (motifs Fig. $15 \mathrm{c}-\mathrm{d}, \mathrm{f}-\mathrm{g}, \mathrm{i}-\mathrm{j})$. Incised decoration (2.9\%), awl impressions (2.9\%) (motif Fig. 15e), handmade applied decoration (5.9\%) (motifs Fig. 15a, b), modelled applied protrusions (2.9\%) and combinations of incised decoration and awl impressions (2.9\%), grooving and awl impressions (2.9\%) (Fig. 15h), chan- nelled decoration and awl impressions (8.8\%) (Fig. 22) are also present.

The Phase 4 pottery assemblage contains 92 fragments, typologically determined as pots $(21.8 \%)$ (Fig. 16k-m, Pl. 11.72 - Pl. 12.75), pitchers (14.1\%) (Fig. 16i-j, Pl. 11.68-71), bowls (5.4\%) (Fig. 16a-e, Pls. 10.59-62, 11.66) and dishes (1.1\%) (Fig. 16f, Pl. $11.63)$. Some $51.1 \%$ of the remaining pottery finds do not belong to these categories. This group includes two miniature dishes (Fig. 15h) (Pl. 11.64), a miniature bowl (Fig. 15g) (Pl. 11.65), a spoon ( $\mathrm{Pl}$. 12.77), ladles ( $\mathrm{Pl}$. 12.78), a decorated object (Pl. $12.79)$ and fragments of handles, lugs and rims (e.g. Pl. 12.76) (Fig. 23).

\section{Characteristics of pottery production of phases 1,2 and 4}

There are noticeable differences in the production technologies of the pottery of phases 1,2 and 4. The most common fabrics of the earliest phase are LM09 and LM12 (Fig. 17). Both are distinguished by inclusions of quartz, mica, iron oxides and macroscopically unidentified white material. They differ from one another only in particle size and amounts of mica and quartz. In Phases 2 and 4, fabrics LM01 and LM08 prevail in roughly equal proportions (Fig. 17). These two fabrics include quartz, mica and iron oxides. Fabrics differ from one another in size and quantity. It is important to stress that a substantial proportion of LM09 occurs only in the earliest phase. It is followed by LM06 and LM11 (Fig. 17).

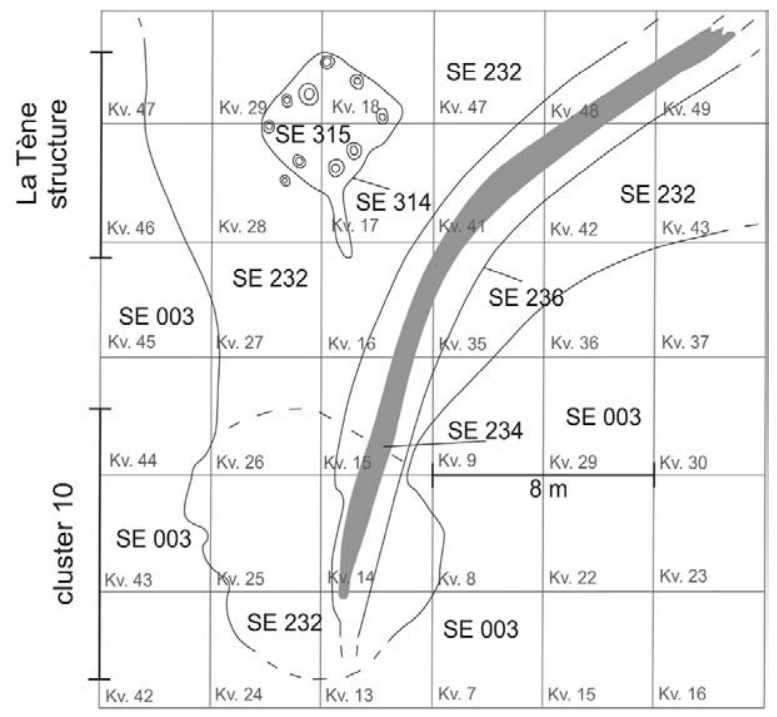

Fig. 6. Location of the alluvium layer (Phase 4), with the La Tène structure (SE 314/315) cut into it, the palaeochannel (Phase 5) and cluster 10 (sketch). 
Most of the fabrics in phases 2 and 4 are very finegrained. Most of the Phase 1 pottery is fine-grained (Fig. 18).

We documented three methods of surface treatment of unfired pottery. Sponging is most common in all phases. In addition, smoothing is present in Phase 1 , and smoothing and burnishing are present in phases 2 and 4 (Fig. 19). Clay slip is not frequently applied before firing in any phase.

Firing under incomplete oxidising conditions prevails. Compared to Phase 1, phases 2 and 4 show slightly larger proportion of incomplete oxidising conditions with reducing conditions at the end of the firing process and oxidising conditions with reducing conditions at the end of the firing process. On the contrary, the proportion of incomplete oxidising and oxidising conditions of firing is lower. Phases 2 and 4 are also characterized by reducing conditions of firing (Fig. 20).

The hardness of pottery assemblages of phases 1,2 and 4 differs from one another. Most of the Phase 1 pottery is very hard (7,8 and 9 on Mohs' scale), while the pottery of phases 2 and 4 is hard ( 3 and 4 on Mohs' scale) (Fig. 21).

Comparison of the proportions of decoration techniques shows differences among phases 1, 2 and 4. Phase 1 contains equal proportions of grooving (motifs Fig. 10f-g), awl impressions (motif Fig. 10a, e) and handmade applied decoration (motifs Fig. 10 b-d) (Fig. 22. Phase 1). Phases 2 and 4 show a high percentage of grooving and channelled decoration (motifs Fig. 12d-f, h-i, k-n, Fig. 15c-d, f-g, i-j), while applied decoration (motifs Fig. 12b-c, motif Fig. 15a-b) and awl impressions (motif Fig. 15e) are less frequent (Fig. 22. Phases 2 and 4).

Decoration is always applied to the exterior upper parts of vessels (Pls. 1.6-8, 2.12, 3.15-18, 4.20, 22, 23 , etc.). Pots mainly carry their decoration on shoulders (Pls. 2.12, 3.15, 17, 4.20, 7.46, 48, 49, 8.50, $10.58,11.72,12.74)$ and sometimes on shoulder-toneck transitions (Pls. 9.55, 12.75) or necks (Pls. 3.18, $9.52,11.73)$.

It is important to note that all the pot necks of phases 2 and 4 are decorated with a bunch of continuous horizontal lines (Figs. 12h, i, 15f, g). The only pot with a decorated neck from Phase 1 shows bunches of vertical lines (Fig. 10f).

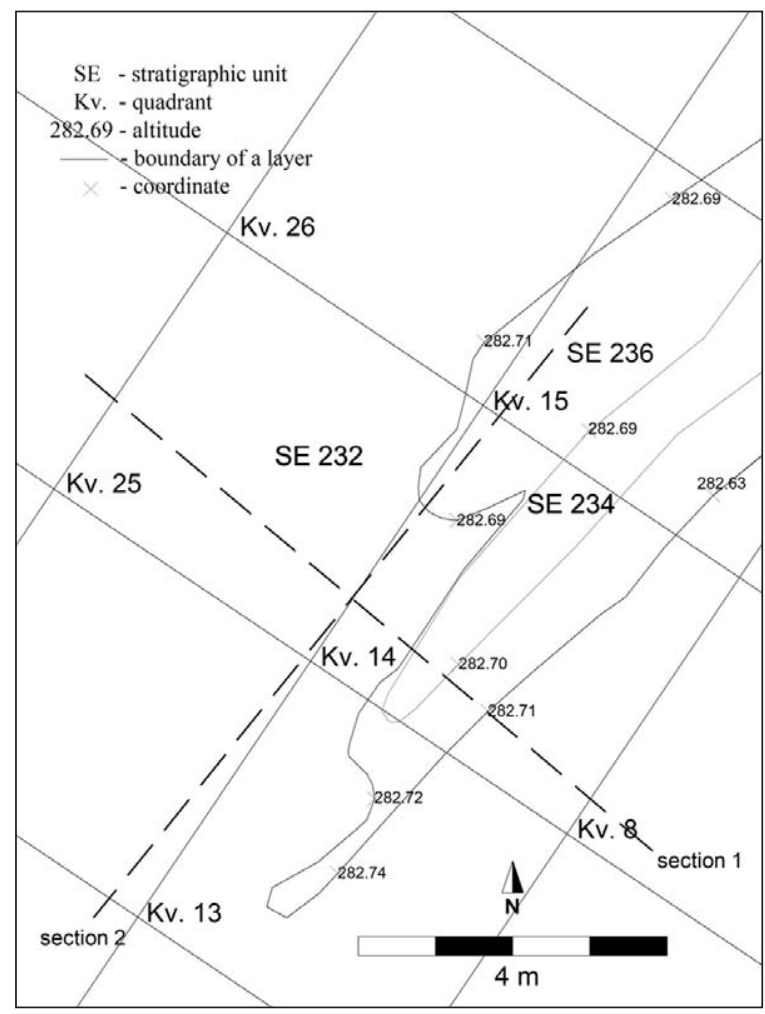

Fig. 7. Plan. Phase 5.

Pots are the most common forms of pottery in all phases (Fig. 23). Phase 1 is characterised by pots with convex shoulders and short necks (Pl. 3.13, $14,18)$. One example of this form was also found in Phase 2 (Pl. 9.52) and one in Phase 4 (Pl. 11.73). Pots with biconical bodies and almost cylindrical necks of various sizes (Pls. 2.11, 12, 4.20), a pot with an extremely rounded lower-to-upper body transition (Pl. 4.19) and a neck-less pot (Pl. 2.9) are also typical of Phase 1 . The most common form of Phase 2 pots are pots with convex shoulders and cylindrical necks (Pls. 7.48, 49, 10.58).

Single-handled pitchers (Fig. 23) are also frequent in phases 2 and 4 (Pls. 7.41-45, 11.68-71). This form is not present in Phase 1.

Dishes and bowls occur in all phases of cluster 10 (Fig. 23). Phase 1 shows a greater number of dishes and bowls with bevelled lips (Pl. 1.3-5). Biconical bowls with everted lips (Pl. 1.6, 7), a dish with a spout hole just below the rim (Pl. 1.8), a dish/bowl with a hollow, slightly concave foot (Pl. 1.1), and a miniature dish/bowl with hollow, slightly concave foot (Pl. 1.2) are also typical. The most common form of bowls and dishes of phases 2 and 4 has a vertical or slightly inverted lip (Pls. 4.22-23, 5.25, 27-29, 6.35, 37, 40, 10.57, 61, 62, 11.66) (Pls. 4.22-23, $5.25,27-29,6.35-37,40,10.57,61,62,11.63)$. 


\begin{tabular}{|c|c|}
\hline FABRIC & MACROSCOPIC DESCRIPTION \\
\hline LMo1 & Very fine grained fabric with quartz $(1 \mathrm{O})$, mica $(2 \mathrm{O})$ and iron oxides $(3 \mathrm{R}, 2 \mathrm{R})$ inclusions. \\
\hline LMo2 & Very fine grained fabric with quartz $(1 \mathrm{O})$, mica $(2 \mathrm{O})$ and iron oxides $(3 \mathrm{R}, 2 \mathrm{O})$ inclusions. \\
\hline LMo3 & Very fine grained fabric with quartz $(2 \mathrm{R}, 1 \mathrm{O})$, mica $(2 \mathrm{O})$ and iron oxides $(3 \mathrm{R}, 2 \mathrm{Z})$ inclusions. \\
\hline LMo4 & Very fine grained fabric with quartz $(2 R, 1 O)$, mica $(3 Z, 2 Z)$ and iron oxides $(3 R)$ inclusions. \\
\hline LMo5 & Very fine grained fabric with quartz $(2 R, 1 O)$, mica $(3 R, 2 Z)$ and iron oxides $(4 R, 3 R, 2 Z)$ inclusions. \\
\hline LMo6 & Fine grained fabric with quartz $(2 Z, 1 O)$, mica $(3 R, 2 Z)$, organic matter $(3 R)$ and iron oxides $(3 R, 2 R)$ inclusions. \\
\hline LMo7 & Fine grained fabric with quartz $(2 \mathrm{Z}, 1 \mathrm{O})$, mica $(3 \mathrm{R}, 2 \mathrm{Z})$, and iron oxides $(3 \mathrm{R})$ inclusions. \\
\hline LMo8 & Fine grained fabric with quartz $(3 R, 2 R, 1 O)$, mica $(3 R, 2 Z)$ and iron oxides $(2 R)$ inclusions. \\
\hline LMo9 & $\begin{array}{l}\text { Fine grained fabric with quartz }(3 R, 2 R, 1 O) \text {, mica }(4 R, 3 R, 2 Z) \text {, iron oxides }(3 R, 2 R) \text { and unidentified white mate- } \\
\text { rial }(3 R) \text { inclusions. }\end{array}$ \\
\hline LM10 & $\begin{array}{l}\text { Fine grained fabric with quartz }(3 R, 2 R, 1 O) \text {, mica }(3 R, 2 Z) \text {, iron oxides }(3 Z, 2 O) \text { and unidentified white material } \\
(3 R) \text { inclusions. }\end{array}$ \\
\hline LM11 & Fine grained fabric with quartz $(5 R, 3 R, 1 O)$, mica $(3 R, 2 Z)$ and iron oxides $(3 R)$ inclusions. \\
\hline $\mathrm{LM}_{12}$ & $\begin{array}{l}\text { Fine grained fabric with quartz }(3 R, 2 Z, 1 O) \text {, mica }(3 R, 2 Z) \text {, iron oxides }(3 R, 2 R) \text { and unidentified white material } \\
(3 R) \text { inclusions. }\end{array}$ \\
\hline $\mathrm{LM} 13$ & Fine grained fabric with quartz $(3 \mathrm{R}, 2 \mathrm{Z}, 1 \mathrm{O})$, mica $(3 \mathrm{Z}, 2 \mathrm{O})$ and iron oxides $(3 \mathrm{R})$ inclusions. \\
\hline LM14 & Medium grained fabric with quartz $(3 \mathrm{R}, 2 \mathrm{O}, 1 \mathrm{O})$, mica $(3 \mathrm{R}, 2 \mathrm{Z})$ and iron oxides $(3 \mathrm{Z}, 2 \mathrm{Z})$ inclusions. \\
\hline$\overline{L M} 15$ & $\begin{array}{l}\text { Medium grained fabric with quartz }(3 \mathrm{R}, 2 \mathrm{O}) \text {, mica }(3 \mathrm{R}, 2 \mathrm{Z}) \text {, organic matter }(3 \mathrm{R}) \text { and iron oxides }(4 \mathrm{R}, 3 \mathrm{R}, 2 \mathrm{O}) \\
\text { inclusions. }\end{array}$ \\
\hline $\mathrm{LM} 16$ & Medium grained fabric with quartz $(3 \mathrm{R}, 2 \mathrm{O})$, mica $(3 \mathrm{R}, 2 \mathrm{Z})$ and iron oxides $(3 \mathrm{R})$ inclusions. \\
\hline $\mathrm{LM} 17$ & Medium grained fabric with quartz $(3 Z, 2 R, 1 O)$, mica $(3 R, 2 Z)$ and iron oxides $(4 R, 3 R)$ inclusions. \\
\hline $\mathrm{LM} 18$ & Medium grained fabric with quartz $(3 Z, 2 Z, 1 O)$, mica $(3 R, 2 Z)$ and iron oxides $(3 R)$ inclusions. \\
\hline LM19 & Medium grained fabric with quartz $(3 \mathrm{Z}, 2 \mathrm{O})$, mica $(2 \mathrm{Z})$ and iron oxides $(2 \mathrm{R})$ inclusions. \\
\hline$\overline{\mathrm{LM} 2 \mathrm{O}}$ & $\begin{array}{l}\text { Medium grained fabric with quartz }(4 R, 3 Z, 2 Z, 1 O) \text {, mica }(3 R, 2 Z) \text {, organic matter }(3 R) \text { and iron oxides }(3 Z) \text { in- } \\
\text { clusions. }\end{array}$ \\
\hline LM21 & Coarse grained fabric with quartz $(3 \mathrm{O}, 2 \mathrm{O})$, mica $(2 \mathrm{Z})$ and iron oxides $(3 \mathrm{R})$ inclusions. \\
\hline $\mathrm{LM} 22$ & Very fine grained fabric with quartz $(1 \mathrm{O})$, calcium carbonate $(3 \mathrm{R})$, mica $(2 \mathrm{R})$ and iron oxides $(3 \mathrm{R})$ inclusions. \\
\hline 123 & matter $(3 R)$ an \\
\hline
\end{tabular}

Fig. 8. Pottery fabrics found in cluster 10 and their macroscopic description. Granularity of inclusions, followed by their frequency per $\mathrm{cm}^{2}$ are shown in brackets (according to Horvat 1999).2

Some of these dishes and bowls have spouting nozzles Pls. 5.26, 11.66) or ring-feet (Pl. 6.33).

\section{Chronological evaluation of pottery assembla- ges from phases 1, 2 and 4}

Absolute dates for the three phases of cluster 10 from Radvanje are not available yet. In order to chronologically determine the pottery assemblage, we therefore had to compare and contrast it with pottery assemblages from other sites that have already been dated.

The most convincing comparisons can be found at Neo-Eneolithic sites from central and south-eastern Slovenia and the Late Neolithic site of Ozalj-Stari grad, Croatia.
Moverna vas and Ajdovska jama both yielded preserved and documented stratigraphy and are comparable to the studied site. Phase 1 is comparable with the second earliest, i.e. Moverna vas 4 , settlement phase. Pottery assemblages show similar hollow, slightly concave feet, covered with slip (compare Pl. 1.1 with Tomaž 1999.Pl. MV20.1-3), dishes with a spout hole just below the rim (compare Pl. 1.8 with Tomaž 1999.Pl. MV19.1), bowls with bevelled lips (compare bowl form Pl. 1.3 with Tomaž 1999.Pl. MV19.2 and spout with Pl. MV17.4) and decoration of dishes with a line of punctate decoration (compare Pl. 1.8 with Tomaž 1999.Pls. MV17.4, MV18.1). Pots with convex shoulders and short cylindrical or slightly sloping necks are popular in both phases (compare Pl. 3.13, 14, 18 with Tomaž 1999. Pls. MV22.1-3, MV24.1, MV25. 1-2). It is important

2 Granularity of inclusions $(1: \geq 0.25 ; 2: 0.26$ to $0.50 ; 3: 0.51$ to $2.00 ; 4: 2.01$ to $3.00 ; 5: \leq 3.01 \mathrm{~mm})$, followed by their frequency (R: $>5, Z: 5$ to $10,0<10)$ are shown in brackets. 


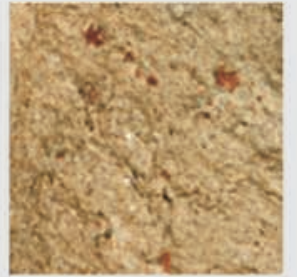

LM01

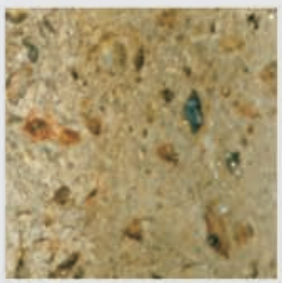

LM05

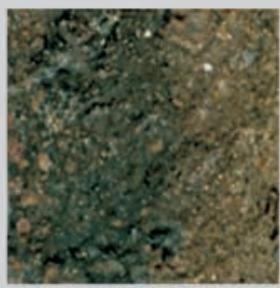

LM08

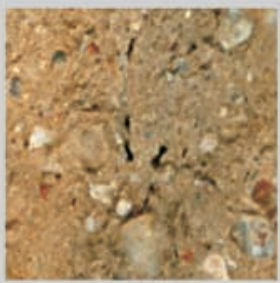

LM12

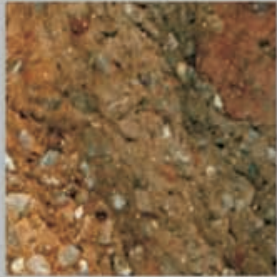

LM15

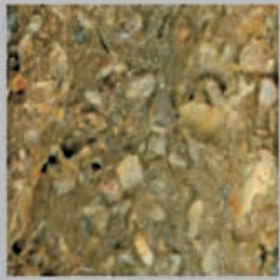

LM19

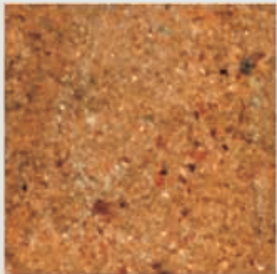

LM02

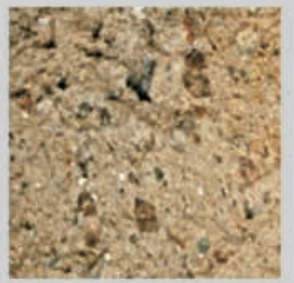

LM06

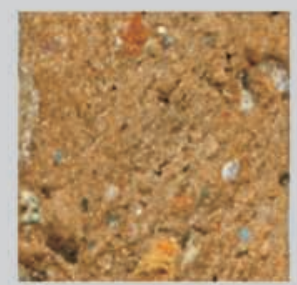

LM09

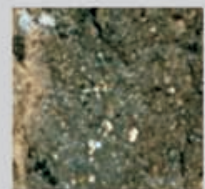

LM13

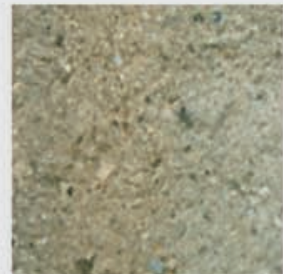

LM03

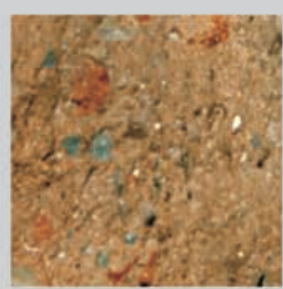

LM10

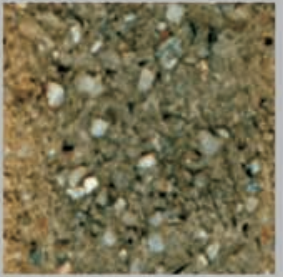

LM16

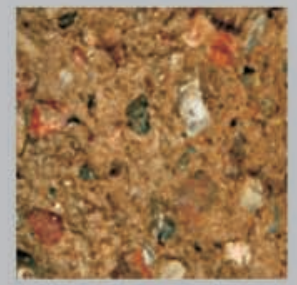

LM20

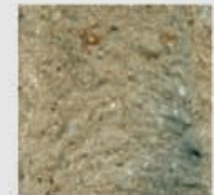

LM04
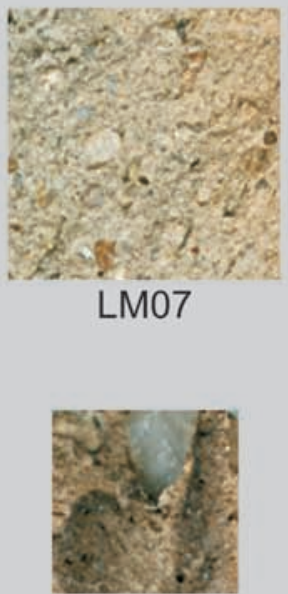

LM11

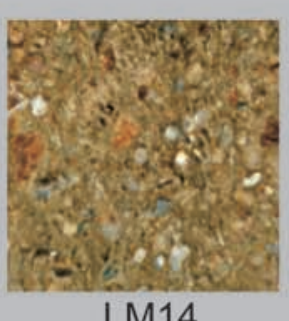

LM14

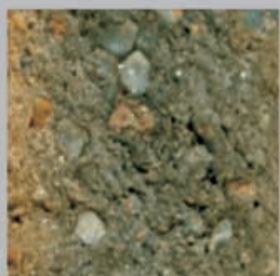

LM17

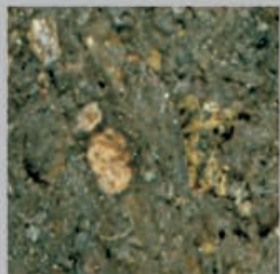

LM18

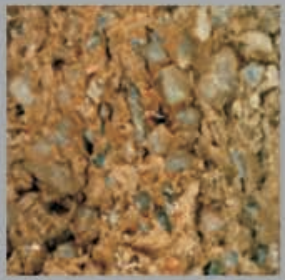

LM21

$\square$ very fine grained, $\square$ fine grained, $\square$ medium grained, $\square$ coarse grained

Fig. 9. Neolithic pottery fabrics and their granularity. Scale 3:1 


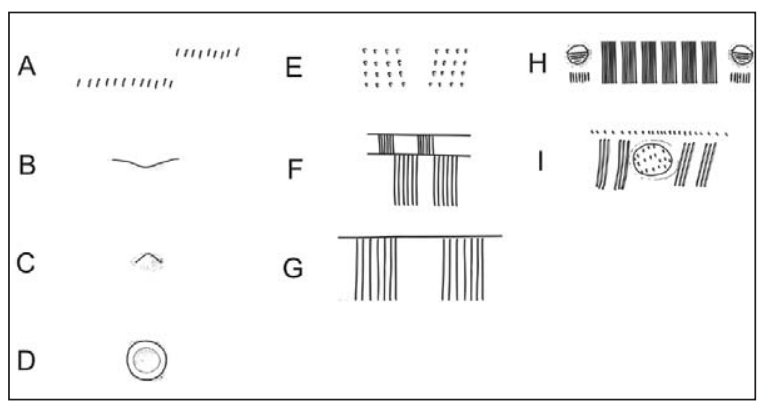

Fig. 10. Decorative motifs. Phase 1.

to note that their necks carry decoration consisting of bunches of vertical incisions (see also Budja 1992. 103, Fig. 4: Phase 4).

Pottery from phases 2 and 4 of cluster 10 is comparable to settlement phases 5 and 6 at Moverna vas. These phases show similarities in dishes and bowls with vertical or slightly inverted lips (compare Pls. 4.22, 5.27, 29, 6.34, 36, 10.62 with Tomaž 1999.Pls. MV33.1-2, MV34.1), in small dishes and bowls of simple forms (miniature dishes and bowls at Radva- nje) (compare Pl. 6.38 and Pl. 11.64, 65 with Tomaž 1999.Pl. MV28.3, 6, 7), and pitchers, which are not known from earlier phases of Moverna vas (compare Pls. 7.42, 43, 11.70 with Tomaž 1999.Pls. MV31.2, 3, MV34.5), and in the decoration of necks and shoulders of pots with bunches of continuous horizontal lines (compare Pls. 9.52, 11.73 with Tomaž 1999.Pls. MV29.3, MV35.12-13) (see also Budja 1992.103, Fig. 4: Phase 5-6).

Phase 1 of cluster 10 is comparable with the oldest horizon of Ajdovska jama. Both phases are characterised by dishes/bowls with hollow, slightly concave feet, covered with slip (compare Pl. 1.1 with Horvat 1986.Pl. 1.2), dishes with a spout hole just below the rim (compare Pl. 1.8 with Horvat 1986. $P l$. 2.1), pots with short convex shoulders and long steeply sloping necks (compare Pl. 3.17 with Korošec 1975.Pl. 9.1), pots with short necks, and necks of pots that carry decoration of bunches of vertical lines (compare Pl. 3.18 with Horvat 1986.Pls. 1.3, 2.4, 5).

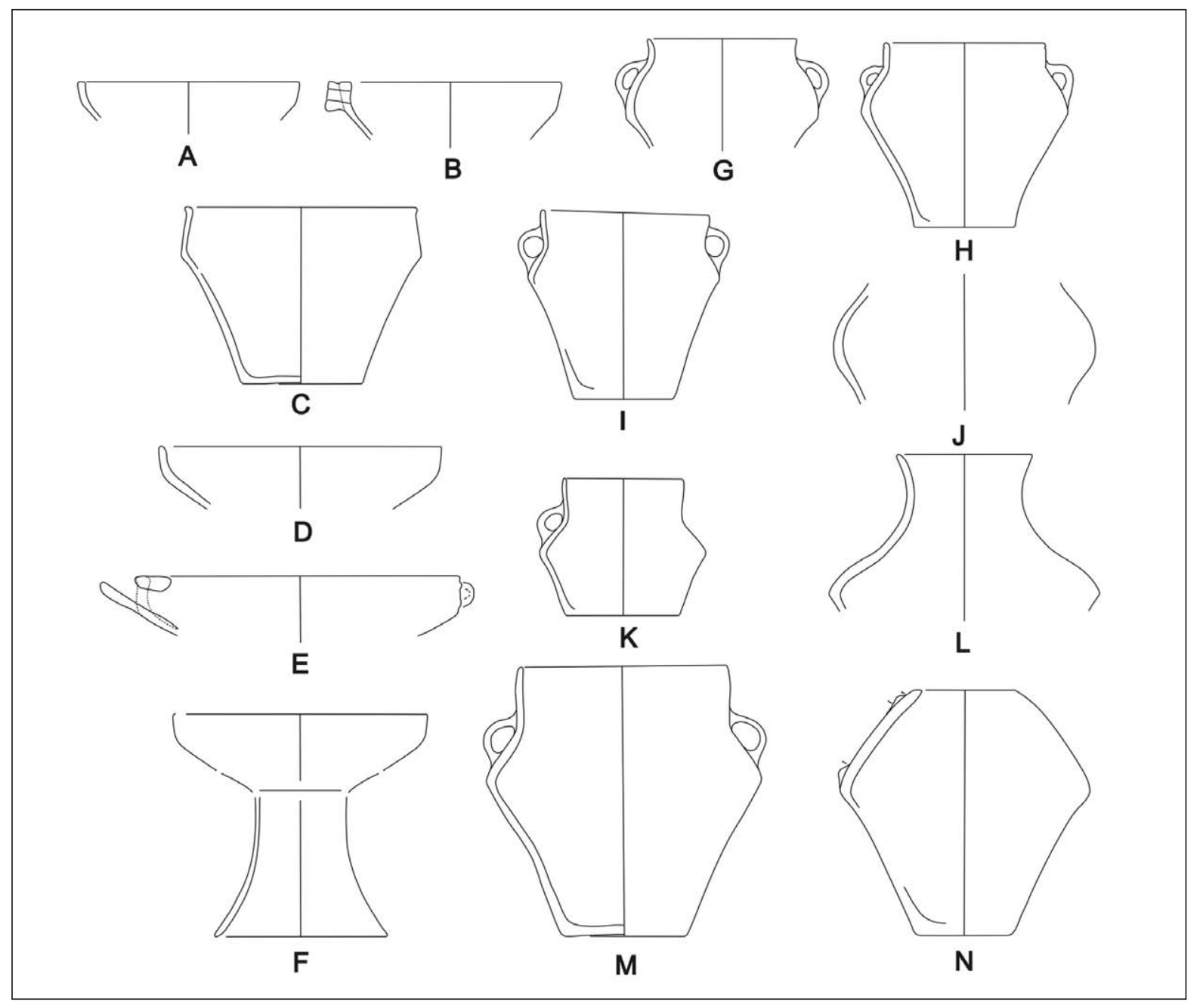

Fig. 11. Vessel forms. Phase 1. 


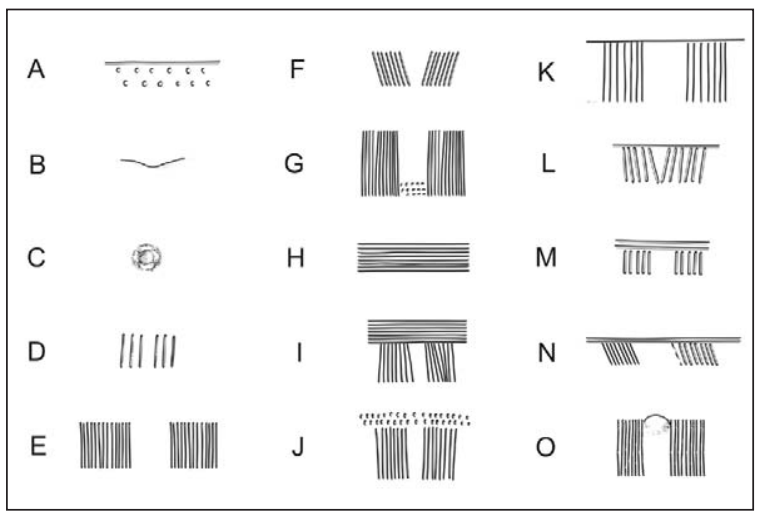

Fig. 12. Decorative motifs. Phase 2.

Pottery from phases 2 and 4 of cluster 10 shows an excellent comparison with the phase of cave burials in Ajdovska jama, which followed the oldest horizon of the site. These phases all contain bowls with verti- cal or slightly inverted lips and spouting nozzles (compare Pl. 11.66 with Korošec, Uršič 1965.Pl. 1.2 and Pl. 5.26 with Korošec 1953.Pl. 11.9), almost identical dishes with bevelled lips (compare Pl. 6.32 with Korošec 1975.Pl. 8.3 and Pl. 6.39 with Pl. 6.2), small dishes of simple forms (compare Pl. 11.64 with Korošec 1975.Pl. 11.4), similar forms and decoration of pitchers (compare Pl. 7.41-45 and Pl. 11.68-71 with Horvat 1989.Pl. 1-9), comparable pots with long sloping necks (compare Pl. 8.50 with Korošec 1975.Pl. 8.1) and similar pot decoration (compare Pl. 11.72 with Horvat 1986.Pl. 3.1 and Pl. 9.52 with Korošec 1953.Pl. 5.5).

The Phase 1 pottery of cluster 10 is also comparable with the earliest Late Neolithic finds from Drulovka (compare Pl. 1.4 with Guštin et al. 2005.45:12, Pl. 3.18 with 49:24; Pl. 2.12 with Korošec 1960.Pls.

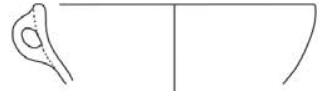

A
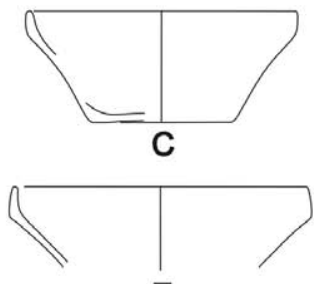

E
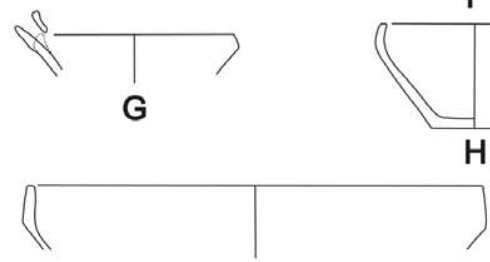

I
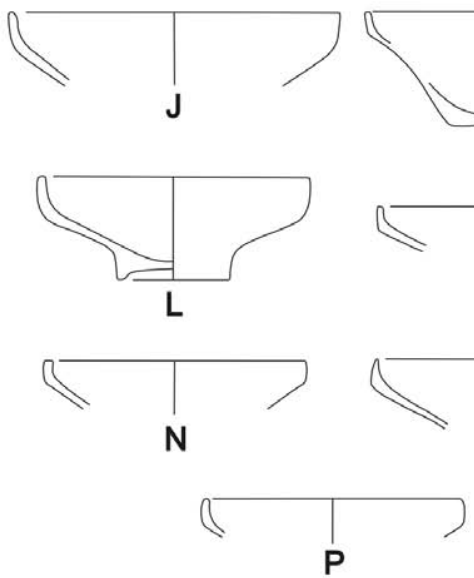
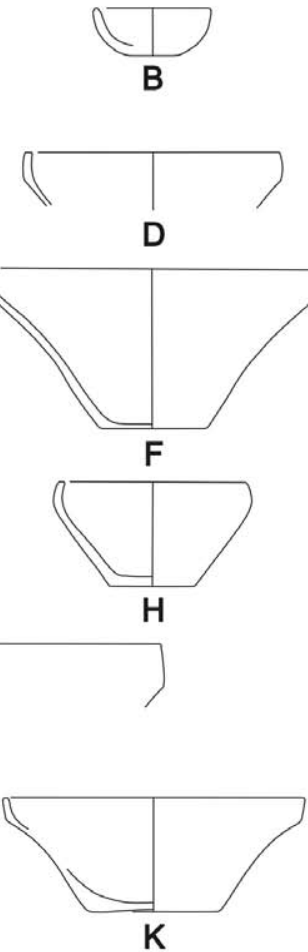

D

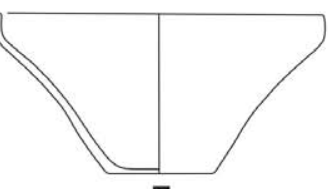

F

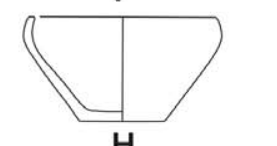

$\mathrm{H}$

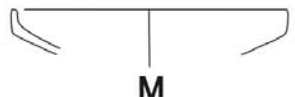

M

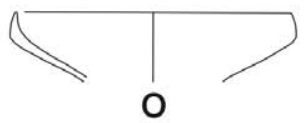

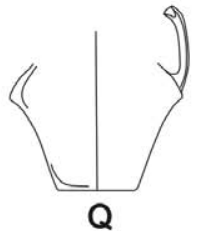
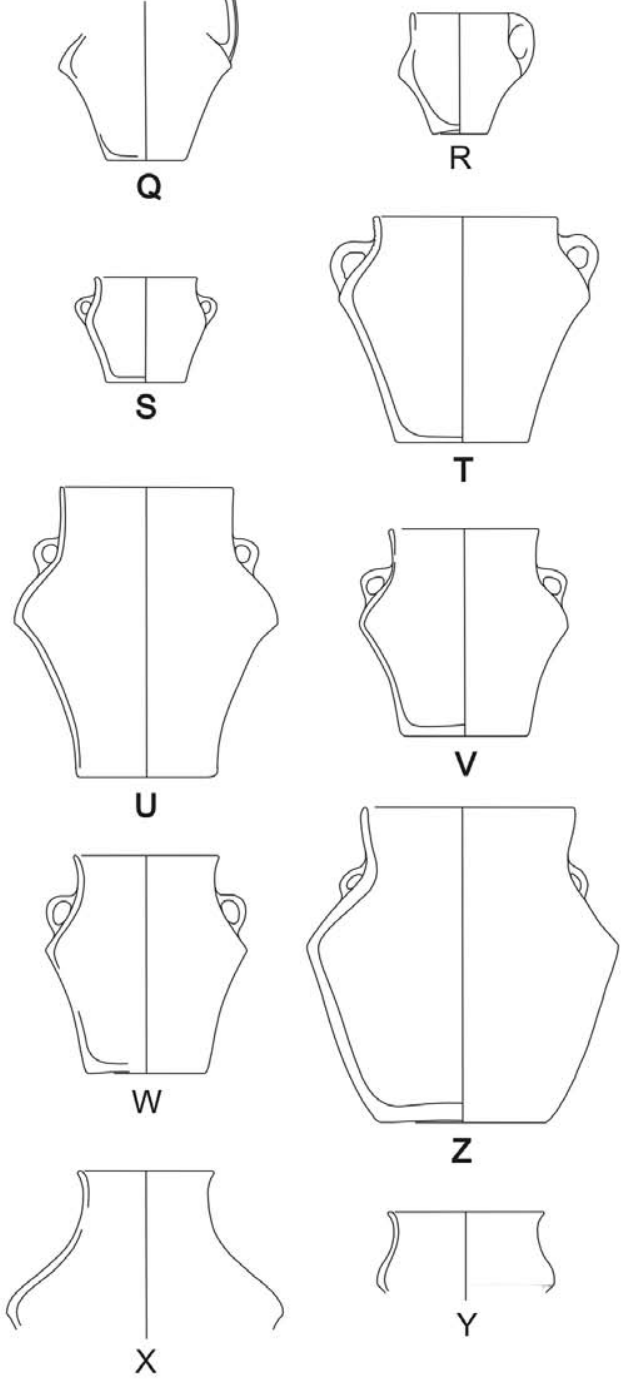

Fig. 13. Vessel forms. Phase 2. 


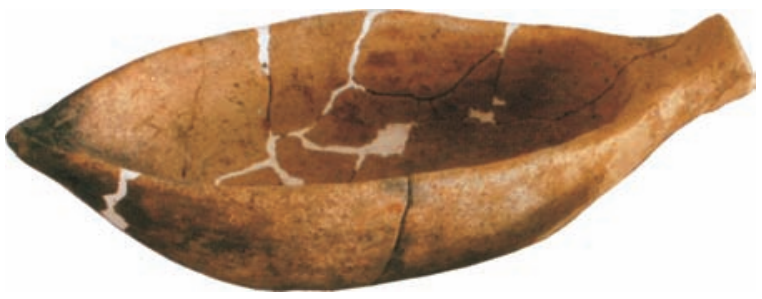

Fig. 14. Lamp with traces of burning.

11.1, 1.7 with Pl. 12.1 and Pl. 3.18 with Pl. 22.6, 9). Moreover, phases 2 and 4 are similar to slightly later finds from Drulovka (Phase Drulovka 2) (compare Pls. 4.22, 5.25, 28 and Pl. 6.37 with Guštin et al. 2005.43:36-38, Pl. 7.41, 42 and Pl. 11.70 with 53:39-41; Pl. 4.22 with Korošec 1960.Pl. 14.2 and Pl. 9.52 with Pls. 17.3, 18.6, 18.8, 19.5, 23.11).

The pottery of cluster 10 can furthermore be correlated with sites Col 1 near Podgračeno (compare Pl. 1.1 with Horvat 2005.Fig. 6.12, 13, Pl. 6.34 with Fig. 6.11, Pl. 5.31 with Fig. 11.16, Pl. 3.15 with Fig. 11.21, Pl. 7.42 with Fig. 11.23, Pl. 7.44 with Fig. 11.25 and Pl. 11.69 with Fig. 11.24), the Neo-Eneolithic horizon of Čatež-Sredno polje (compare Pl. 11.67 with Tiefengraber 2006.233:5 and Pl. 7.43 with 233:6), Grac near Sela pri Zajčjem Vrhu (compare for example Pl. 7.42 with Pavlin 2006.221:64, and Pl. 10.59 with 215:17), Kamnik- Mali Grad (compare T. 5.26 with Sagadin 2005.30:5, Pl. 11.66 with 30:6 and decoration of the pot Pl. 9.52 with 30:8), Gradišče near Stiška vas and Kratna above Kamnik (compare Pl. 4.22 with Velušček 2005.25:21, Pl. 10.8 with $25: 19, \mathrm{Pl}$. 11.73 with $24: 4, \mathrm{Pl}$. 1.1 with $24: 5$ and Pl. 4.22 with $24: 2$ ).
The Phase 1 pottery of cluster 10 is well comparable to pottery from the Late Neolithic site of Ozalj-Stari Grad in nearby Croatia. Both contain similar hollow, slightly sloping feet (compare Pl. 1.1 with TežakGregl 1993.Pl. 1.1), biconical bowls with circular applied decoration (compare Pl. 1.7 with Težak-Gregl 2001.Pl.3.1 and Pl. 1.6 with Težak-Gregl 2005.159: 15), bowls with a spout hole just below the rim (compare Pl. 1.8 with Težak-Gregl 2001.Pl.4.7) and short-necked pots decorated with bunches of vertical lines on their shoulders and necks (compare Pl. 3.18 with Težak-Gregl 2001.159:17, 20, 21).

Pottery found at some Late Neolithic sites of central and south-eastern Slovenia is not comparable to the pottery from cluster 10 . These are Čatež-Sredno polje (Tomaž 2005; Tomaž, Kavur 2006), Dragomelj (Turk, Svetličič 2005) and Resnikov Prekop (Korošec 1964; Tomaž, Velušček 2005; Velušček 2006). These sites are comparable with the earliest phase of Moverna vas. Pots with no shoulders and with long, sloping necks, pots with convex shoulders and steeply sloping necks, and bowls with bevelled lips frequently occur at these sites. Their maximum girths are commonly decorated with applied decoration, often in combination with impressions (compare Tomaž 2005.117:4-5, 119:9,10,13, 121:21, 123:28-31, 125:38,41; Tomaz̆, Kavur 2006.84:5-7, 85:10, 1214, 86:17,18, 87:19; Turk, Svetličič 2005.75:21, 23, 29, 34-35, 77:43, 44, 46; Tomaž, Velušček 2005.95: 23, 25, 97:35; Velušček 2006.Pls. 2.2-4, Pl. 5.1-Pl. 7.1, Pls. 13.1, 14.2, 3.5, 17.13, 14, 18.1-7, 19.4 with Tomaž 1999.Pls. MV5.1, 3, MV9.4, MV10.4, MV11.3, MV14.1). In addition to dishes/bowls with hollow,

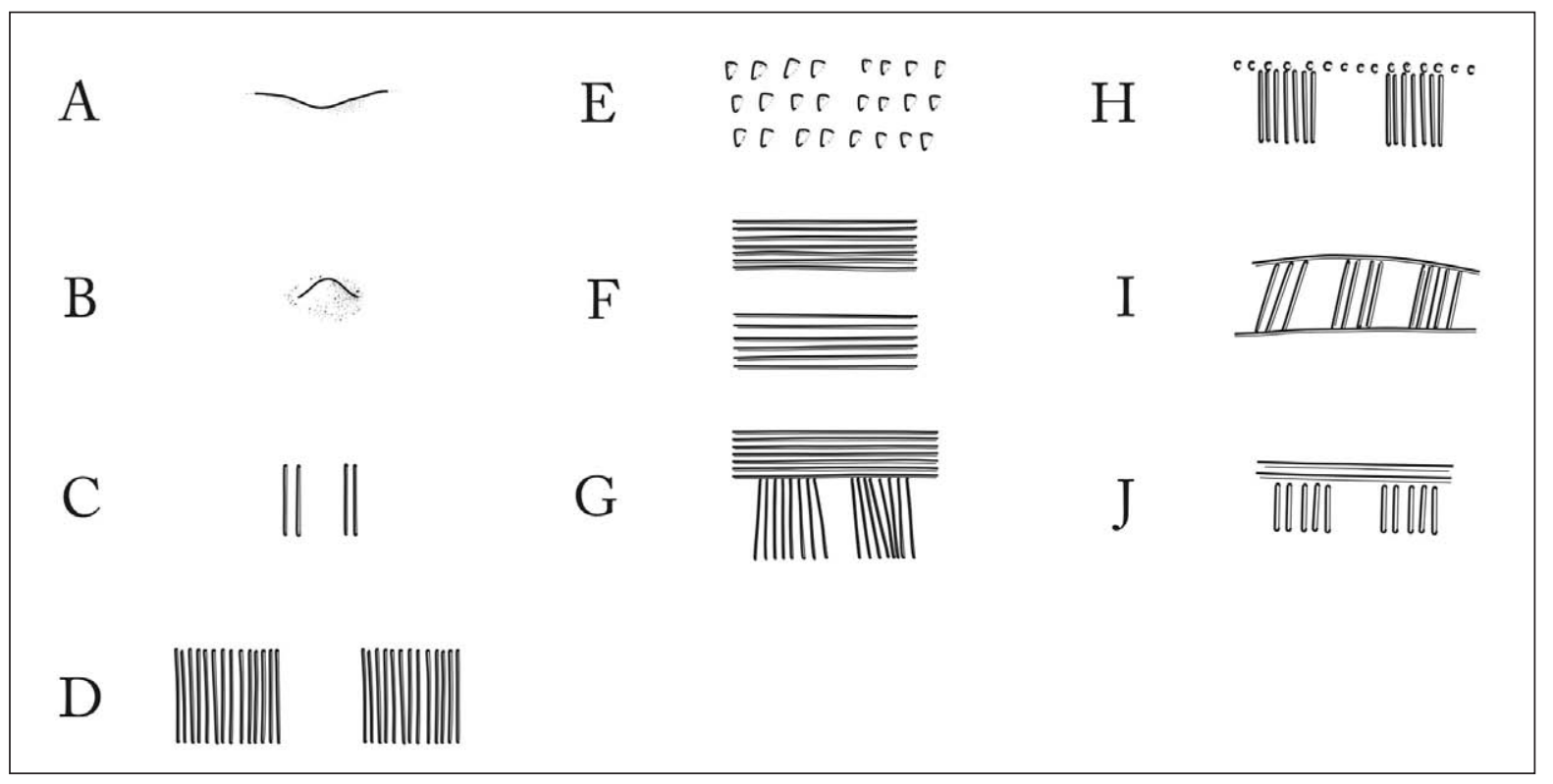

Fig. 15. Decorative motifs. Phase 4. 


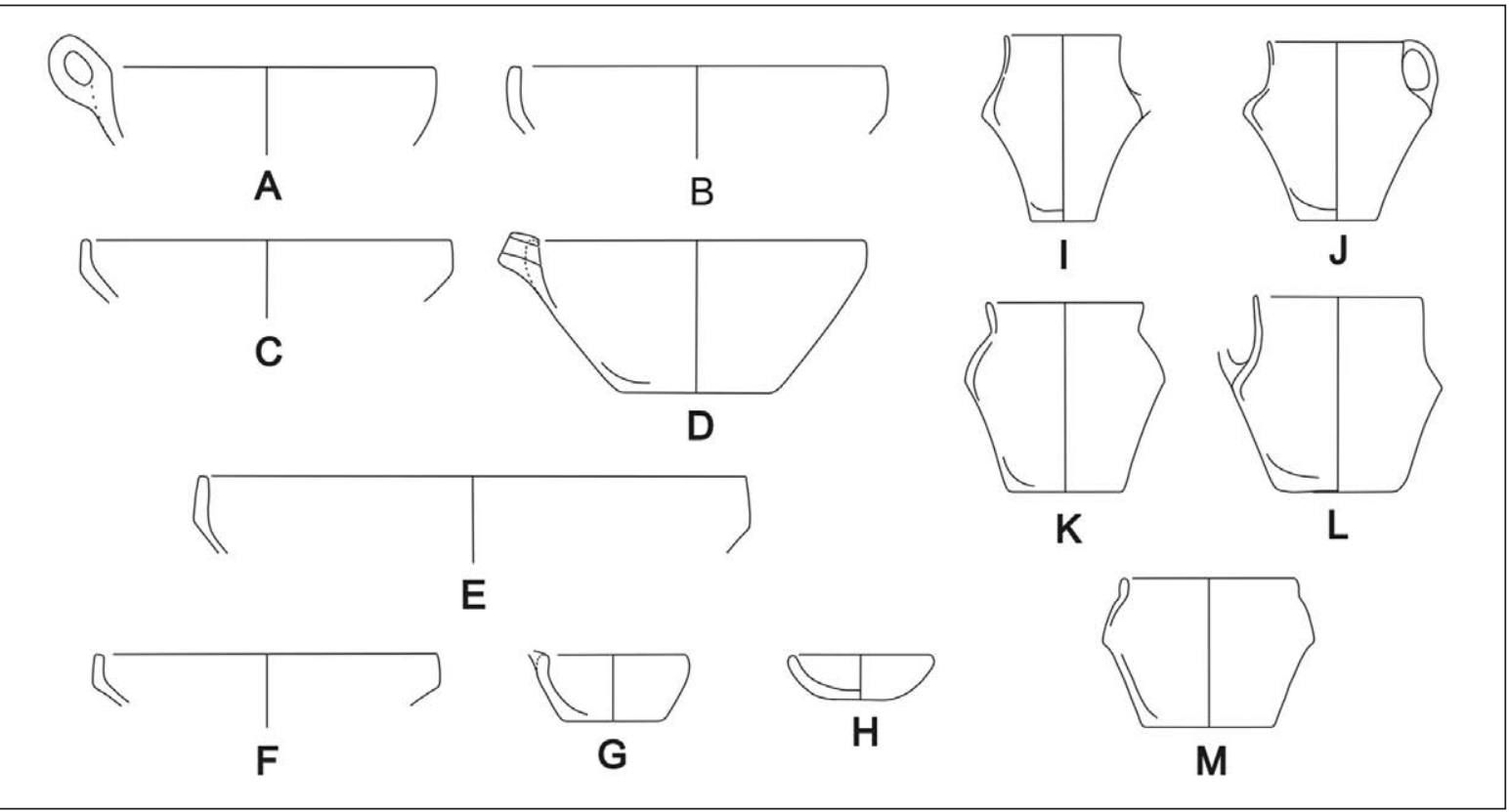

Fig. 16. Vessel forms. Phase 4.

slightly sloping feet, hollow, almost cylindrical feet (compare Tomaž 2005.123:36; 2006.85:10, 86:16; Turk, Svetličič 2005.75:32; Korošec 1964.Pl. 14.5 with Tomaž 1999.Pl. MV3.3, 4) and hollow, coneshaped and short feet are present (Tomaž 2005.117: 7, 123:37; Tomaž, Kavur 2006.85:11, 12, 14, 15; Turk, Svetličič 2005. 75: 22).

\section{Conclusion}

Six phases were recognised within the settlement deposit of Radvanje. Four of them are associated with the settlement, construction and destruction of the recognised structure and everyday activities. Two are related to flowing water activity, and are documented with a layer of alluvium and a palaeochannel.

We noted a great similarity in the pottery assemblages of phases 2 and 4 . However, they both slightly differ from the assemblage of Phase 1 . The differences can be seen mainly in pottery forms and their decoration. Certain deviations also occur in pottery manufacturing technology.

Comparisons with other sites indicate that the Radvanje pottery from phases 1,2 and 4 of cluster 10 dates to the Late Neolithic. The best comparisons can be found at some sites from central and southeastern Slovenia. The Phase 1 pottery can be correlated with pottery of the $4^{\text {th }}$ settlement phase of Moverna vas, the earliest pottery from Drulovka and Ozalj-Stari Grad in Croatia, and it is also similar to the pottery from the earliest horizon of Ajdovska ja$\mathrm{ma}$. The pottery from phases 2 and 4 of cluster 10 is somewhat later. The best comparisons can be made with pottery from Drulovka, which dates to the late Neo-Eneolithic period (Phase Drulovka 2), pottery from the phase of cave burials in Ajdovska jama and pottery from the $5^{\text {th }}$ and $6^{\text {th }}$ settlement phase of Moverna vas. $\mathbf{3 , 4}$

3 I sincerely thank to Mira Strmčnik Gulič from the Maribor Unit of the Institute for the Protection of Cultural Heritage (ZVKDS), Head of the archaeological excavation, who made it possible for me to publish this summary of my undergraduate thesis, which was written under supervision of Prof. Dr. Mihael Budja and submitted to the Department of Archaeology at the University of Ljubljana in 2010.

4 I would like to thank Nives Kokeza for English translation of the text. 


\begin{tabular}{|c|c|c|c|c|c|c|c|c|c|c|c|c|c|}
\hline \multirow[b]{2}{*}{ fabric } & \multicolumn{2}{|c|}{ Phase 1} & \multicolumn{2}{|c|}{ Phase 2} & \multicolumn{2}{|c|}{ Phase 4} & \multirow[b]{2}{*}{ fabric } & \multicolumn{2}{|c|}{ Phase 1} & \multicolumn{2}{|c|}{ Phase 2} & \multicolumn{2}{|c|}{ Phase 4} \\
\hline & pcs. & $\%$ & pcs. & $\%$ & pcs. & $\%$ & & pcs. & $\%$ & pcs. & $\%$ & pcs. & $\%$ \\
\hline LMo1 & 5 & 18,5 & 58 & 35,8 & 41 & 44,6 & $\mathrm{LM}_{13}$ & I & 0,0 & 2 & 1,2 & 1 & 1,1 \\
\hline LMo2 & 1 & 0,0 & 3 & 1,9 & 1 & 0,0 & $\mathrm{LM}_{14}$ & 1 & 0,0 & 1 & 0,0 & 1 & 1,1 \\
\hline $\mathrm{LMO}_{3}$ & 1 & 0,0 & 1 & 0,6 & 3 & 3,3 & LM15 & 1 & 0,0 & 1 & 0,0 & 1 & 1,1 \\
\hline LMo4 & 1 & 0,0 & 3 & 1,9 & l & 0,0 & $\overline{\mathrm{LM}} 6$ & 1 & 3,7 & 10 & 6,2 & 3 & 3,3 \\
\hline LMo5 & 1 & 0,0 & 1 & 0,6 & 1 & 0,0 & LM17 & I & 0,0 & 2 & 1,2 & 3 & 3,3 \\
\hline LMo6 & 1 & 3,7 & I & 0,0 & 1 & 0,0 & $\mathrm{LM}_{18}$ & 1 & 3,7 & 19 & 11,7 & 6 & 6,5 \\
\hline LMo7 & 1 & 0,0 & 11 & 6,8 & 5 & 5,4 & LM19 & 1 & 0,0 & 4 & 2,5 & 3 & 3,3 \\
\hline LMo8 & 3 & 11,1 & 41 & 25,3 & 20 & 21,7 & LM2O & 1 & 0,0 & 3 & 1,9 & 2 & 2,2 \\
\hline LMo9 & 8 & 29,6 & 1 & 0,0 & 1 & 0,0 & $\overline{\mathrm{LM}} 21$ & 1 & 0,0 & 1 & 0,6 & 2 & 2,2 \\
\hline LM10 & 1 & 0,0 & 1 & 0,0 & 1 & 1,1 & LM22 & 1 & 0,0 & 1 & 0,0 & I & 0,0 \\
\hline LM11 & 1 & 3,7 & 1 & 0,0 & 1 & 0,0 & LM23 & I & 0,0 & 1 & 0,0 & I & 0,0 \\
\hline$\overline{\mathrm{LM}} 12$ & 7 & 25,9 & 3 & 1,9 & I & 0,0 & & & & & & & \\
\hline
\end{tabular}

Fig. 17. Quantity and percentage of fabrics (LM). Phases 1, 2 and 4.

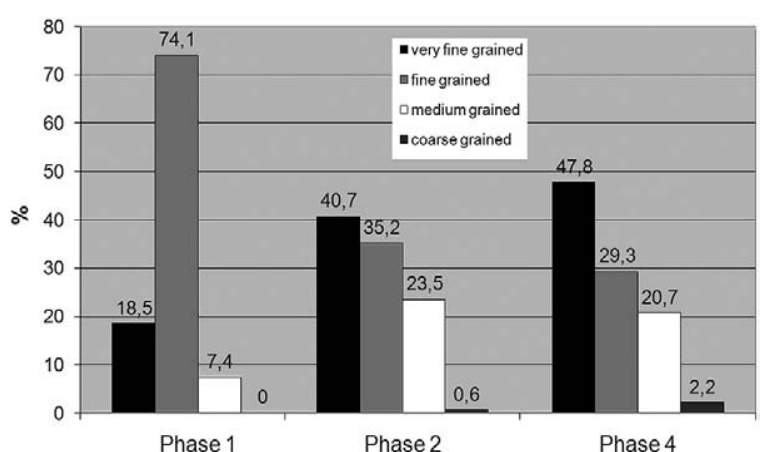

Fig. 18. Percentage of different granularity groups. Phases 1, 2 and 4.

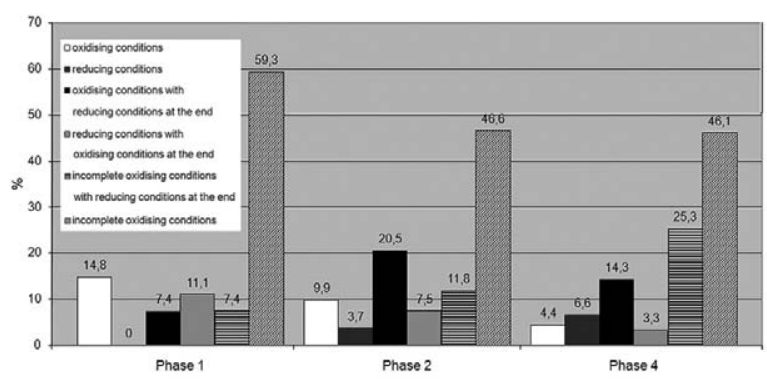

Fig. 20. Percentage of types of firing of pottery. Phases 1,2 and 4.

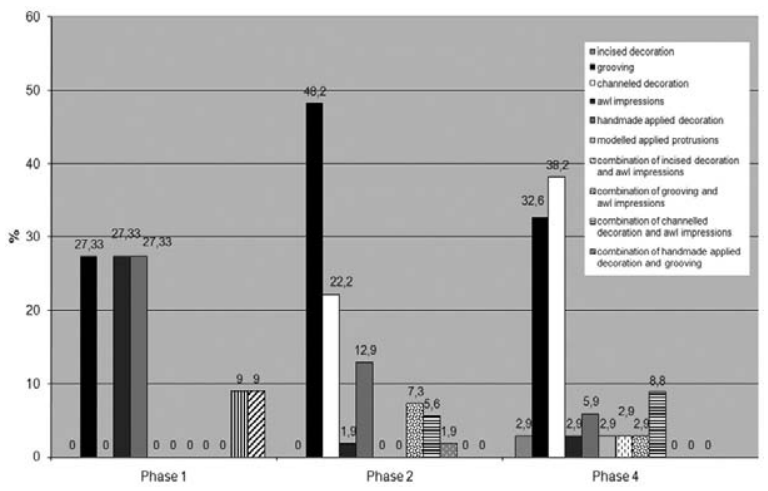

Fig. 22. Percentage of pottery decoration techniques. Phases 1, 2 and 4.

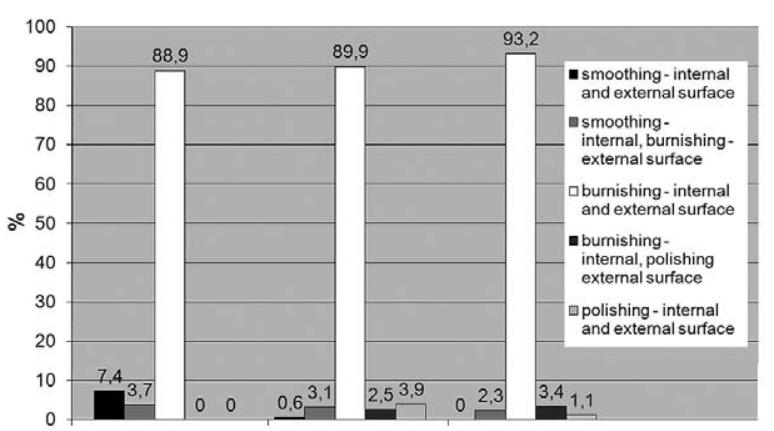

Phase $1 \quad$ Phase 2 Phase 4

Fig. 19. Percentage of unfired surface treatment of pottery. Phases 1, 2 and 4.

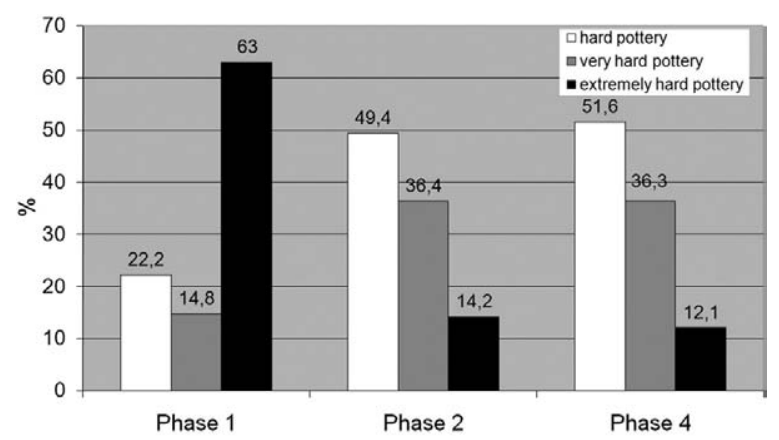

Fig. 21. Percentage of hardness groups. Phases 1, 2 and 4.

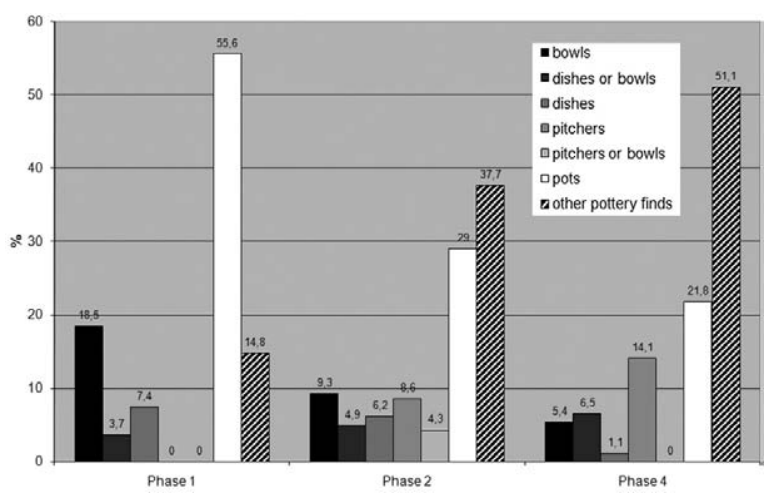

Fig. 23. Percentage of basic vessel forms. Phases 1, 2 and 4. 


\section{REFERENCES}

BUDJA M. 1992. Pečatniki v Slovenskih neolitskih naselbinskih kontekstih. Poročilo o raziskovanju paleolitika, neolitika in eneolitika v Sloveniji 20: 95-109.

GAMS I. 1998. Pokrajinsko ekološka sestava Slovenije. In Gams I., Vrišer I., Geografija Slovenije. Slovenska matica, Ljubljana: 214-243.

GUŠTiN M., TOMAŽ A., KAVUR B. 2005. Drulovka pri Kranju. In M. Guštin (ed.), Prvi poljedelci/First farmers. Annales mediterranea, Koper: 37-42.

HORVAT MA. 1986. Ajdovska jama pri Nemški vasi - desni hodnik. Poročilo o raziskovanju paleolitika, neolitika in eneolitika $v$ Sloveniji 14: 77-88.

HORVAT MI. 1989. Ajdovska jama pri Nemški vasi. Razprave filozofske fakultete. Ljubljana.

1999. Keramika. Tehnologija keramike, tipologija lončenine, keramični arhiv. Razprave filozofske fakultete. Ljubljana.

2005. Col 1 pri Podgračenem. Tipološka opredelitev neolitskega keramičnega zbira SE 002/1/1. In M. Guštin (ed.), Prvi poljedelci/First farmers. Annales mediterranea, Koper: 145-153.

KOPRIVNIK V., STRMČNIK GULIČ M., KAJZER CAFNIK M. 2009. Aktualna arheološka odkritja. Muzejsko razstavišče, 18. maj 2009 - 15. april 2010/Latest archaeological findings. Museum exhibition hall, $18^{\text {th }}$ of May $2009-15^{\text {th }}$ of April 2010. Muzejski listi 36. Pokrajinski muzej, Maribor.

KOROŠEC J. 1953. Kulturne ostaline v Ajdovski jami pri Nemški vasi. Kulturreste in der Hohle Ajdovska jama bei Nemška vas. Razprave Dissertationes 3: 45-107.

1960. Drulovka. Zbornik filozofske fakultete III/4. Univerzitetna založba. Ljubljana.

1964. Kulturne ostaline na kolišču ob Resnikovem prekopu odkrite v letu 1962. Poročilo o raziskovanju neolita in eneolita $v$ Sloveniji 1: 25-46.

KOROŠEC P. 1975. Poročilo o raziskavah v Ajdovski jami 1967. leta. Poročilo o raziskovanju neolita in eneolita $v$ Sloveniji 4: 170-187.

KOROŠEC P., URŠIČ M. 1965. Neolitske in eneolitske ostaline iz okolice Krškega. Poročilo o raziskovanju neolita in eneolita v Sloveniji 2: 55-71.

PAHIČ S. 1972. Arheološko raziskovanje v Mariboru. Posebni odtisi, Univerzitetna knjižnica Maribor.
PAVLIN P. 2006. Grac pri selih pri Zajčjem vrhu. In A. Tomaž (ed.), Od Sopota do Lengyela/Between Sopot and Lengyel. Annales mediterranea, Koper: 211-227.

SAGADIN M. 2005. Nekatere neolitske najdbe $z$ vzhodne Gorenjske. In M. Guštin (ed.), Prvi poljedelci/First farmers. Annales mediterranea, Koper: 29-36.

STRMČNIK GULIČ M. 1990. Podoba antične poselitve med vzhodnim Pohorjem in Dravo. Arheološki vestnik 41: 135-146.

1991. Villa rustica in staroslovansko grobišče Radvanje/Villa rustica und altslawische grabstatte/Villa rustica and old slavic burying place. Zavod za varstvo naravne in kulturne dediščine, Maribor.

TURK P., SVETLIČIČ V. 2005. Neolitska naselbina v Dragomlju. In M. Guštin (ed.), Prvi poljedelci/First farmers. Annales mediterranea, Koper: 113-129.

ŠLOSAR A. 2009. Radvanje: Villa rustica in staroslovansko grobišče. Diplomsko delo. Oddelek za arheologijo Filozofske fakultete, Ljubljana.

TERŽAN B. 1990. Starejša železna doba na Slovenskem Štajerskem. Katalogi in monografije/Catalogi et monographiae 25. Narodni muzej. Ljubljana.

TEŽAK-GREGL T. 1993. Prapovijesno nalazište Ozalj-Stari grad. Opuscula archaeologica 17: 165-173.

2001. The lengyel culture in Croatia. In J. Regenye (ed.), Sites and stones: Lengyel culture in western Hungary and beyond/a review of the current research. Viza Press, Veszprém: 27-35.

2005. Ozalj-Stari grad, neolitička naseobina. In M. Guštin (ed.), Prvi poljedelci/First farmers. Annales mediterranea, Koper: 155-162.

TIEFENGRABER G. 2006. Jungneolitische Funde aus ČatežSredno polje. In A. Tomaž (ed.), Od Sopota do Lengyela/ Between Sopot and Lengyel. Annales mediterranea, Koper: 229-234.

TOMAŽ A. 1997. Tehnološka raziskava lončenine iz Moverne vasi v Beli krajini. Poročilo o raziskovanju paleolitika, neolitika in eneolitika v Sloveniji 24: 113-142.

1999. Časovna in prostorska strukturiranost neolitskega lončarstva: Bela krajina, Ljubljansko barje, Dinarski kras. Tipkopis magistrske naloge. Oddelek za arheologijo Filozofske fakultete, Ljubljana. 
2005. Čatež-Sredno polje. Analiza neolitske keramike iz objektov 055 in 093. In M. Guštin (ed.), Prvi poljedelci/First farmers. Annales mediterranea, Koper: 113129.

TOMAŽ A., VELUŠČEK A. 2005. Resnikov prekop na Ljubljanskem barju 1962 in 2002. In M. Guštin (ed.), Prvi poljedelci/First farmers. Annales mediterranea, Koper: 8799.

TOMAŽ A., KAVUR B. 2006. Zemlja in ogenj. Annales mediterranea, Koper.
VELUŠČEK A. 2005. Kratna nad Kamnikom, Gradišče pri Stiški vasi. In M. Guštin (ed.), Prvi poljedelci/First farmers. Annales mediterranea, Koper: 23-28.

2006. Resnikov prekop - sondiranje, arheološke najdbe, kulturna opredelitev in časovna uvrstitev. In A. Velušček, Resnikov prekop, najstarejša koliščarska naselbina na Ljubljanskem barju/Resnikov prekop, the oldest Pile-Dwelling Settlement in the Ljubljansko barje. Opera Instituti Archaeologici Sloveniae 10, Ljubljana: 19-85.

\section{Appendix}

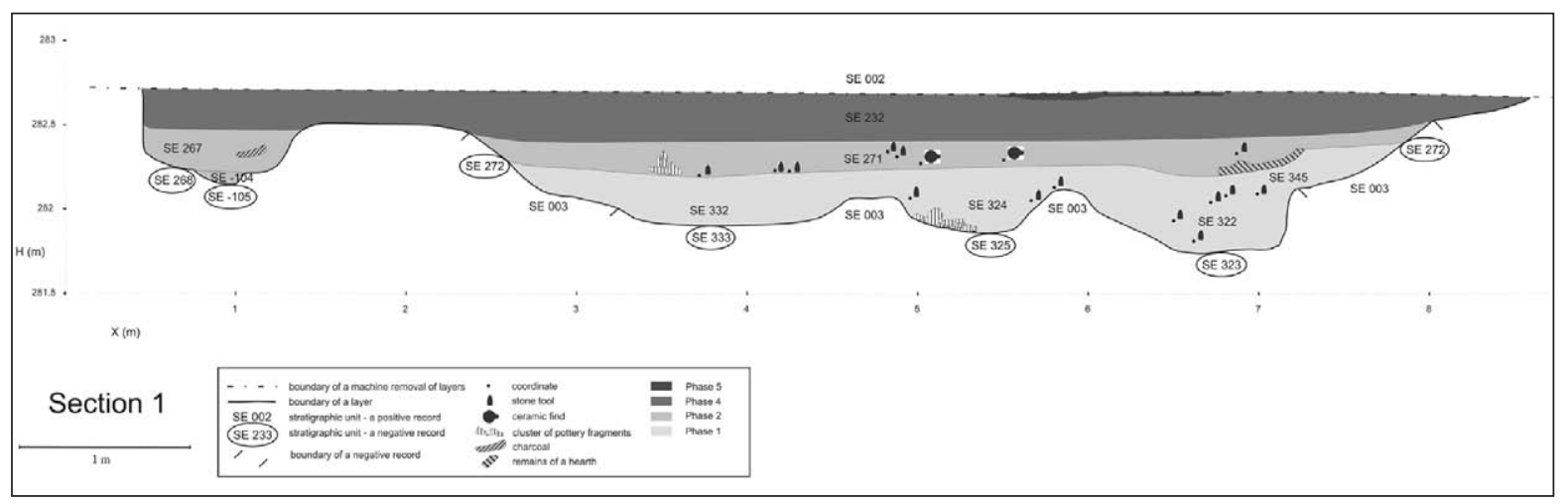

App. 1. Cluster 10, section 1.

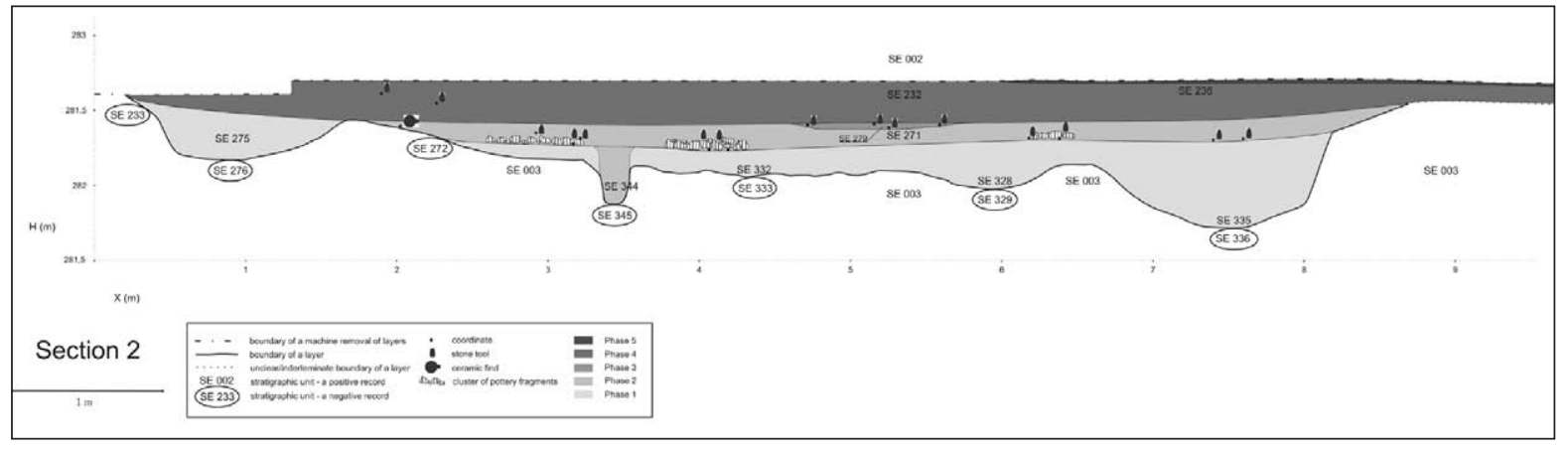

App. 2. Cluster 10, section 2. 

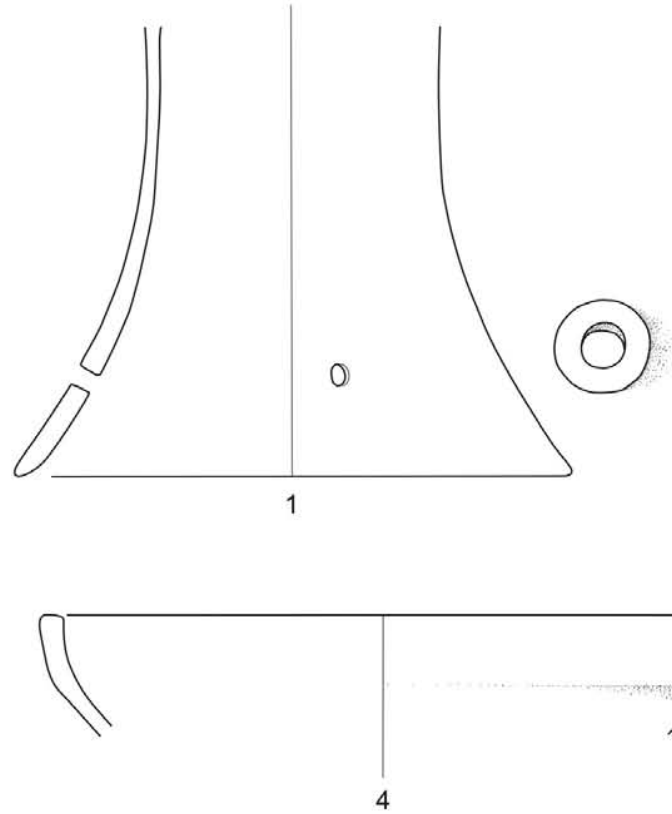
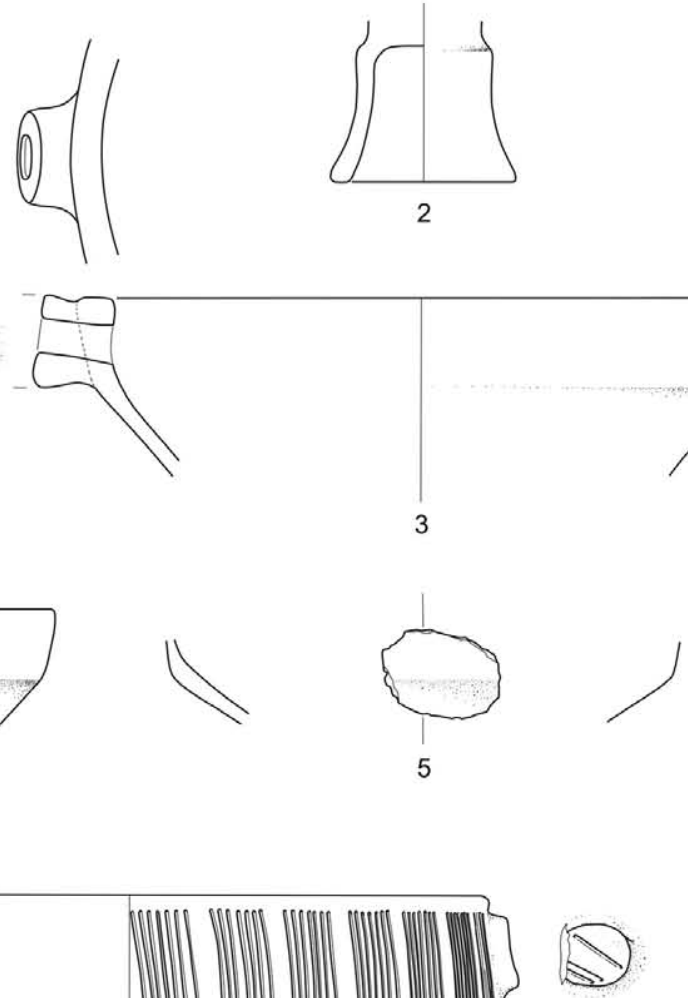

\|lilll
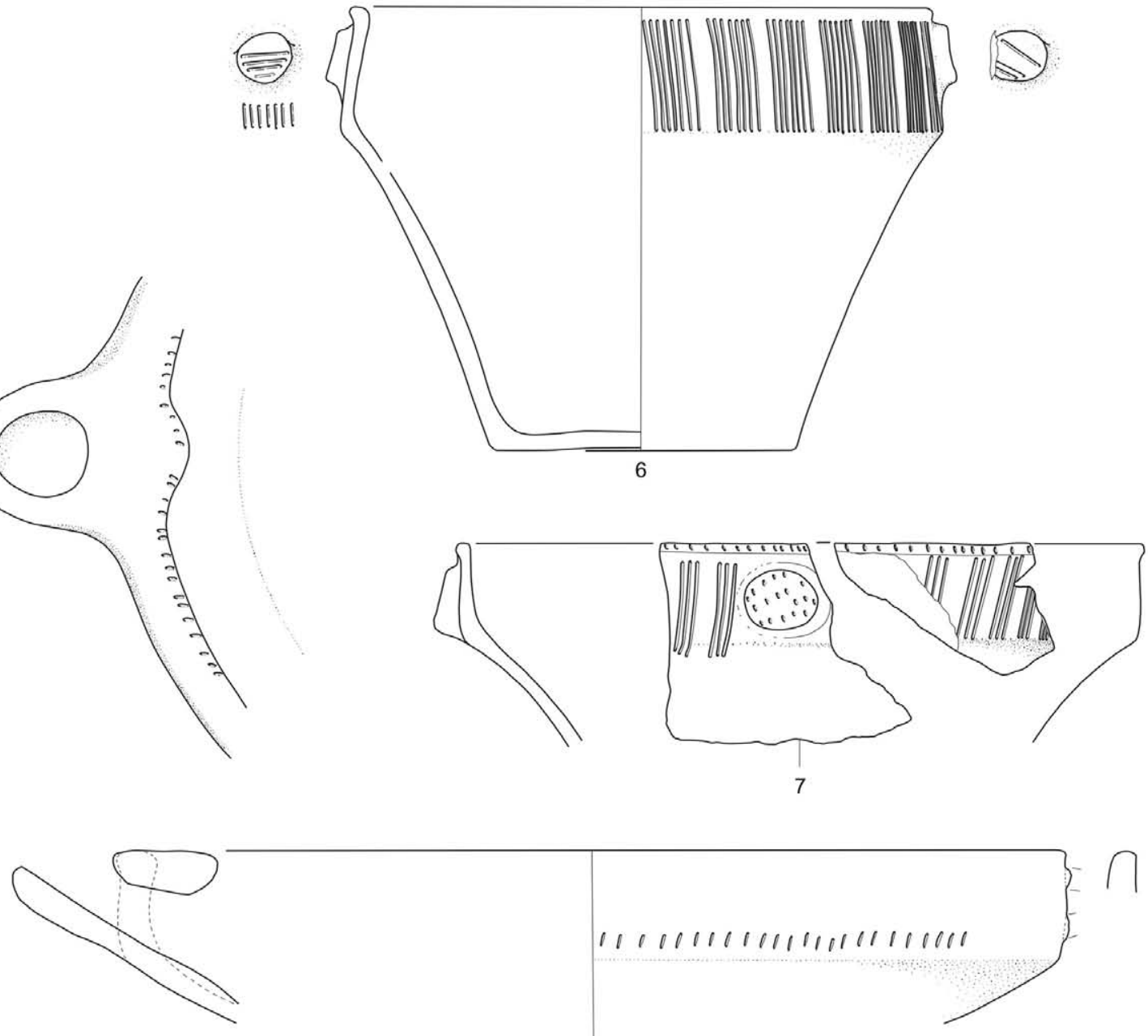

Scale $1: 3$

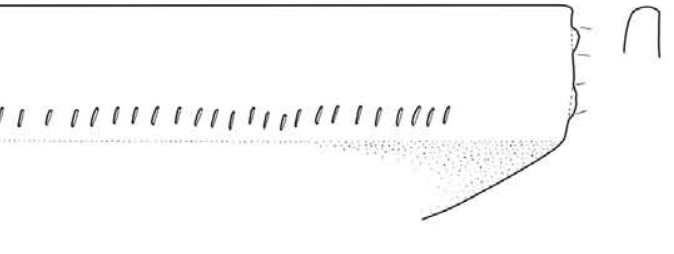

Pl. 1. Zgornje Radvanje, Cluster 10. Ceramic. SE 322 (1-2), SE 324 (5-6), SE ? (3-4, 7-8). Phase 1. 


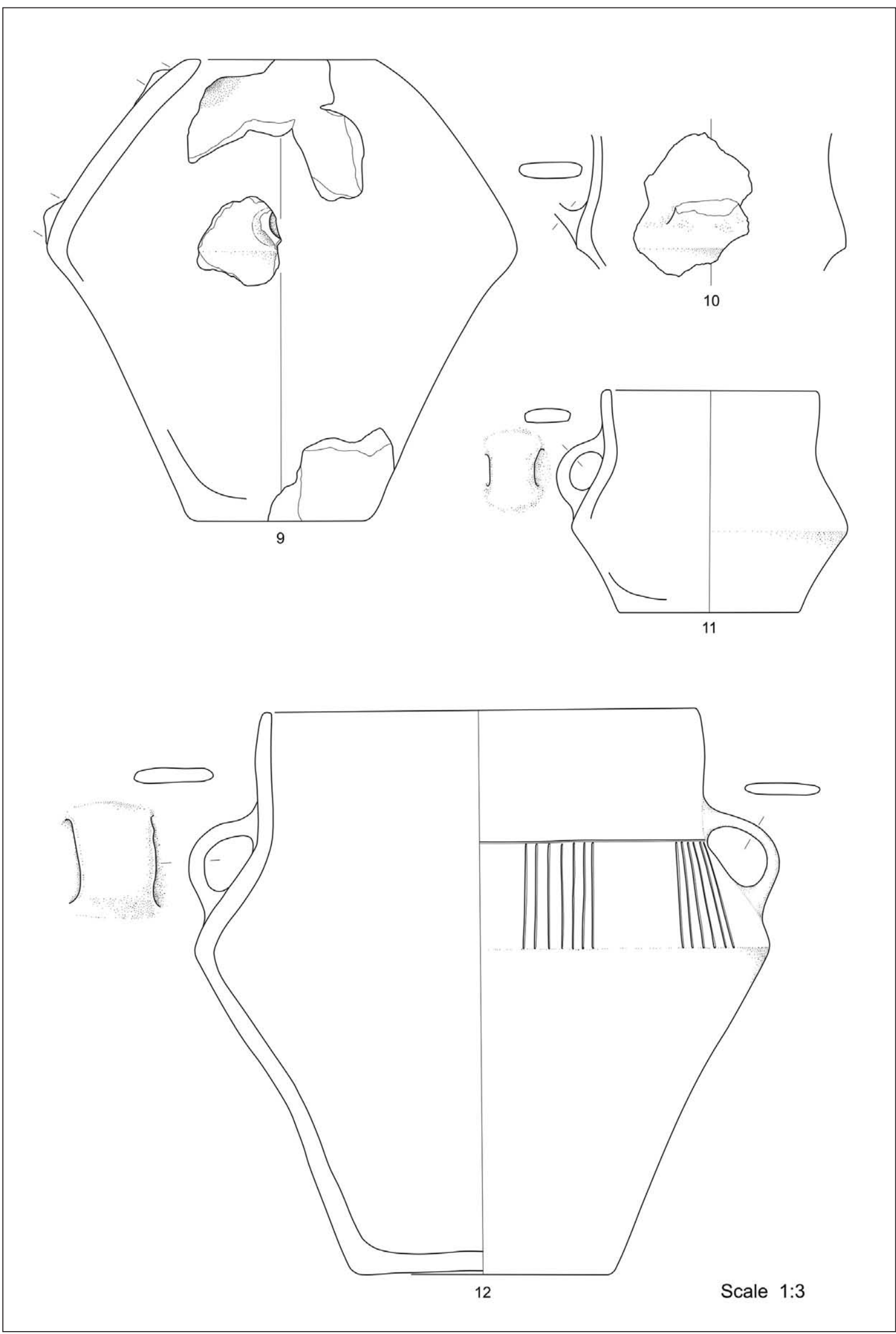

Pl. 2. Zgornje Radvanje, Cluster 10. Ceramic. SE 322 (9-11), SE 324 (12). Phase 1. 


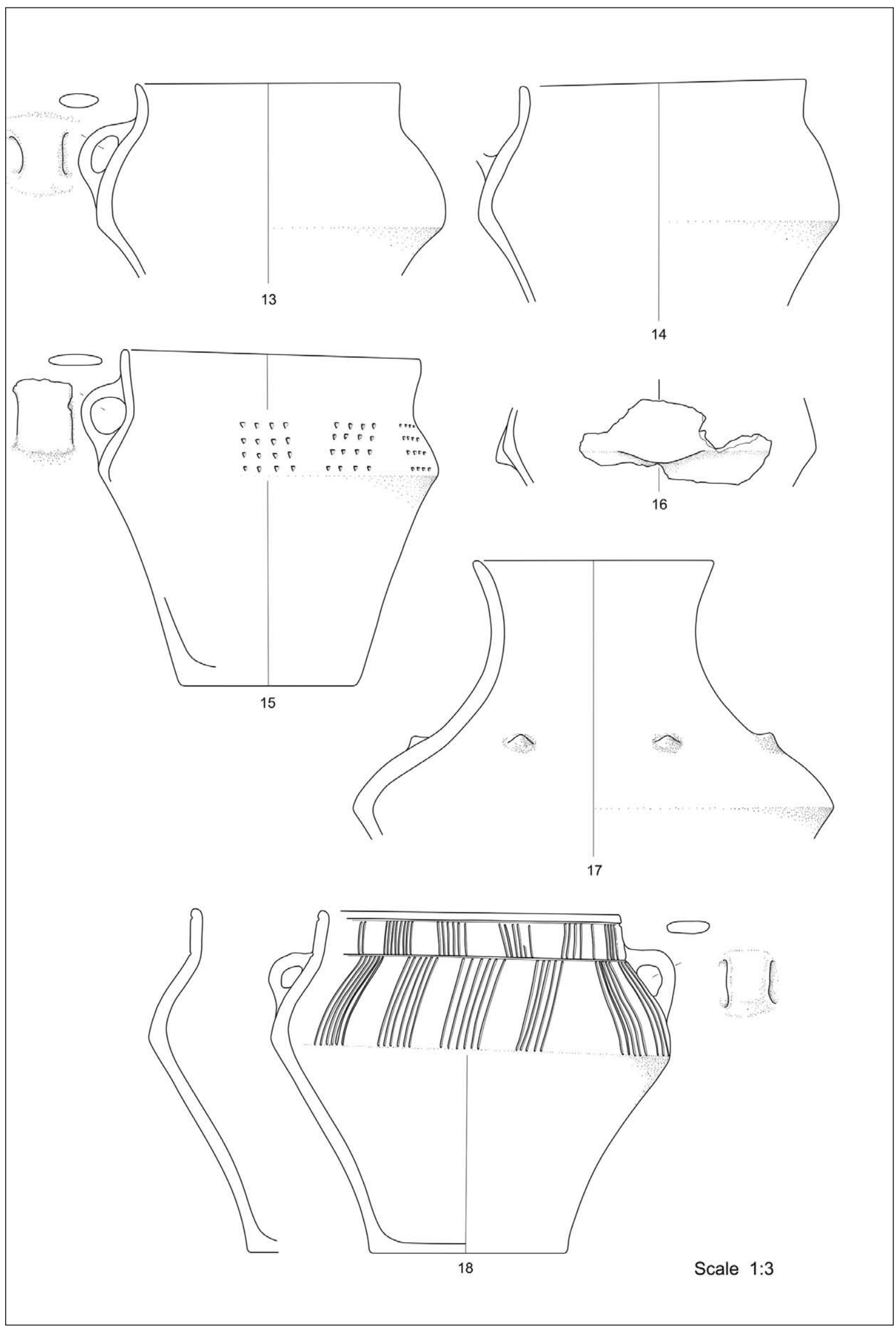

Pl. 3. Zgornje Radvanje, Cluster 10. Ceramic. SE 322 (13), SE 324 (15, 17-18), SE 332 (14, 16). Phase 1. 


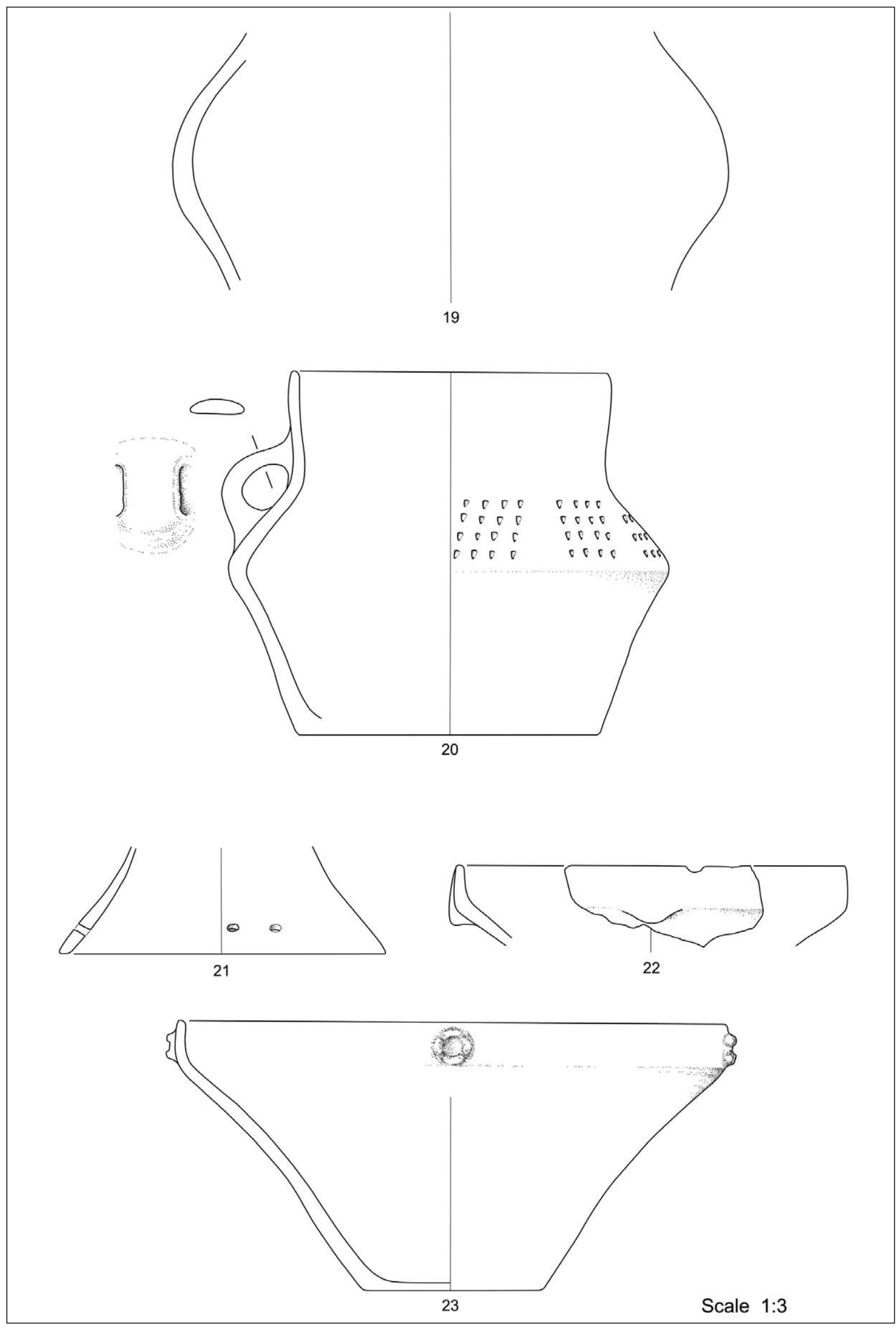

Pl. 4. Zgornje Radvanje, Cluster 10. Ceramic. SE 330 (19-20). Phase 1. SE 271 (21-23). Phase 2. 

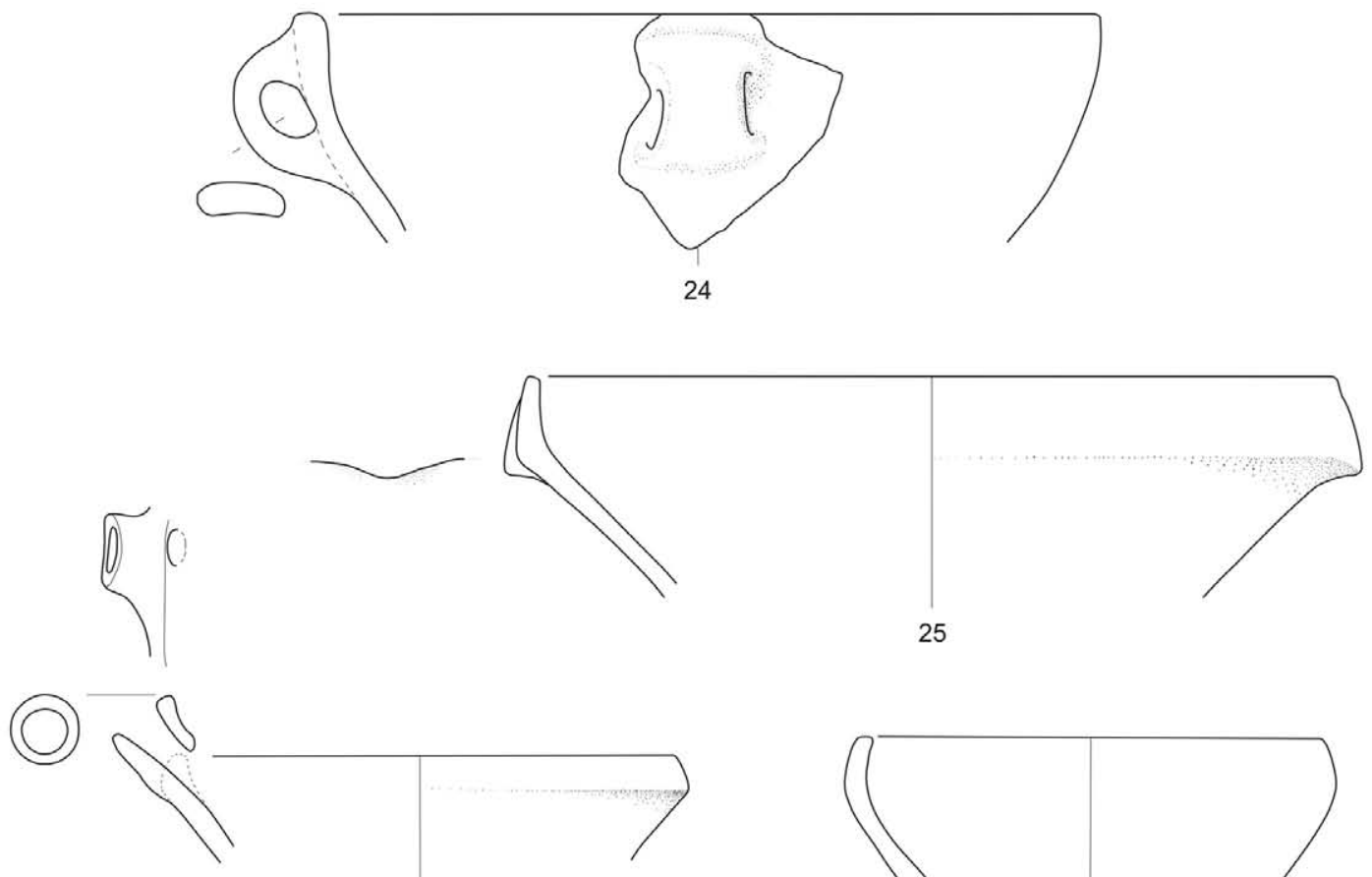

26
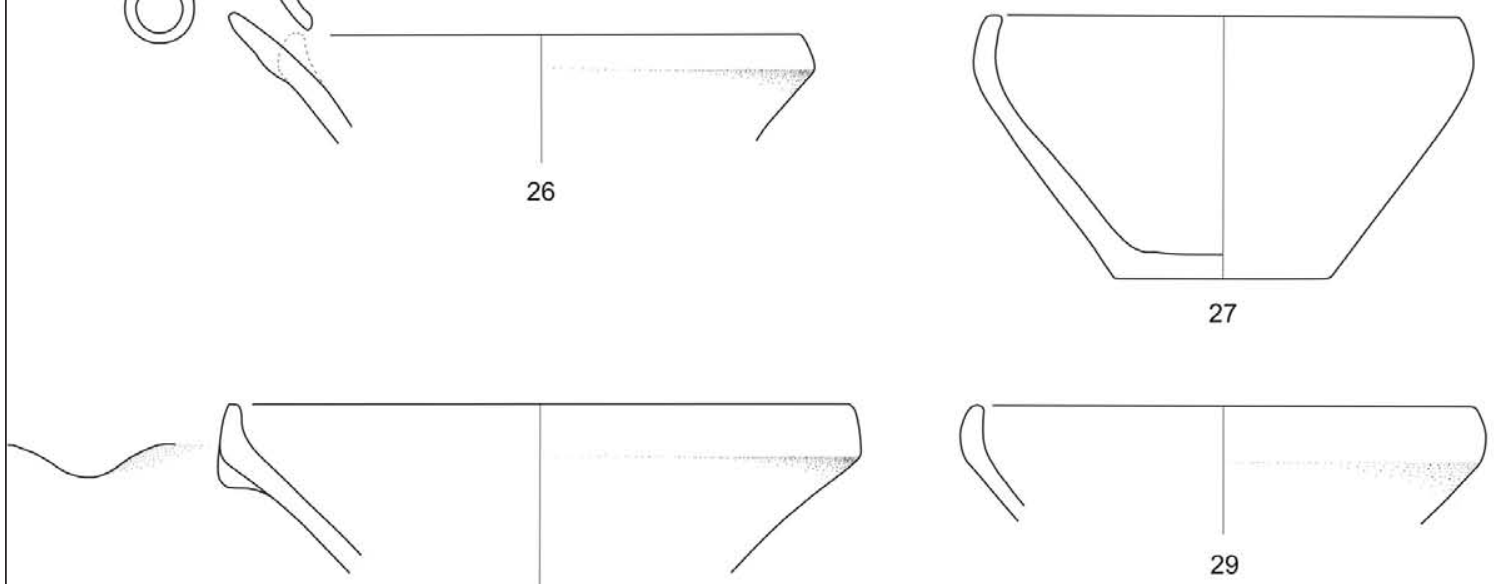

29

28
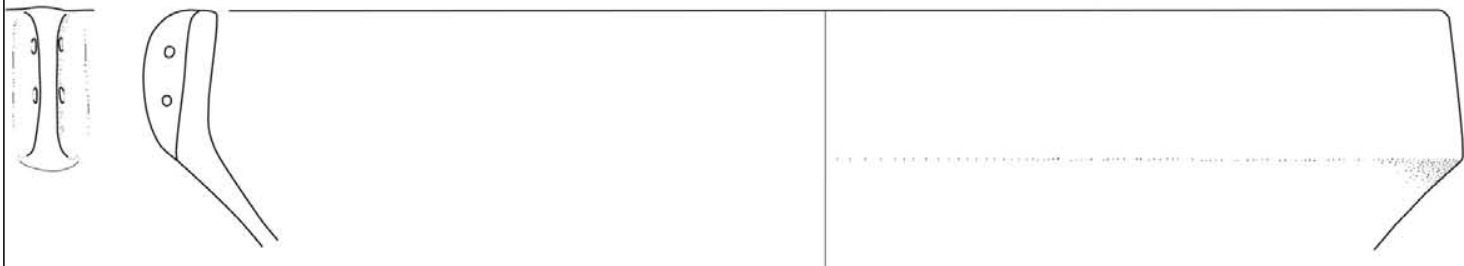

30

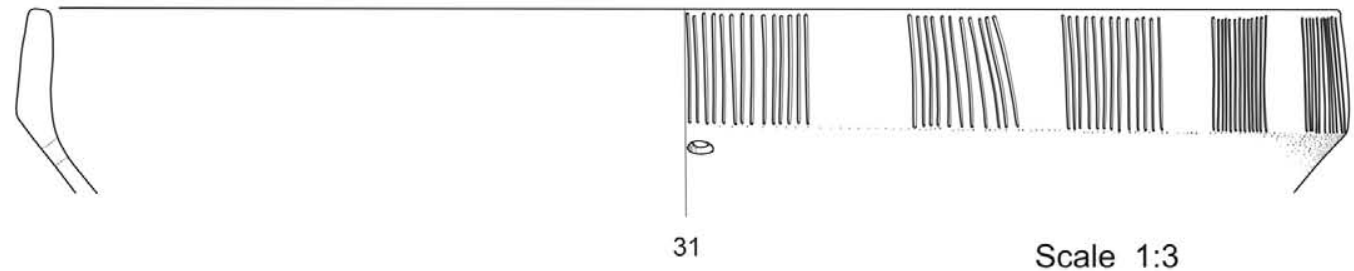

Scale 1:3

Pl. 5. Zgornje Radvanje, Cluster 10. Ceramic. SE 271. Phase 2. 


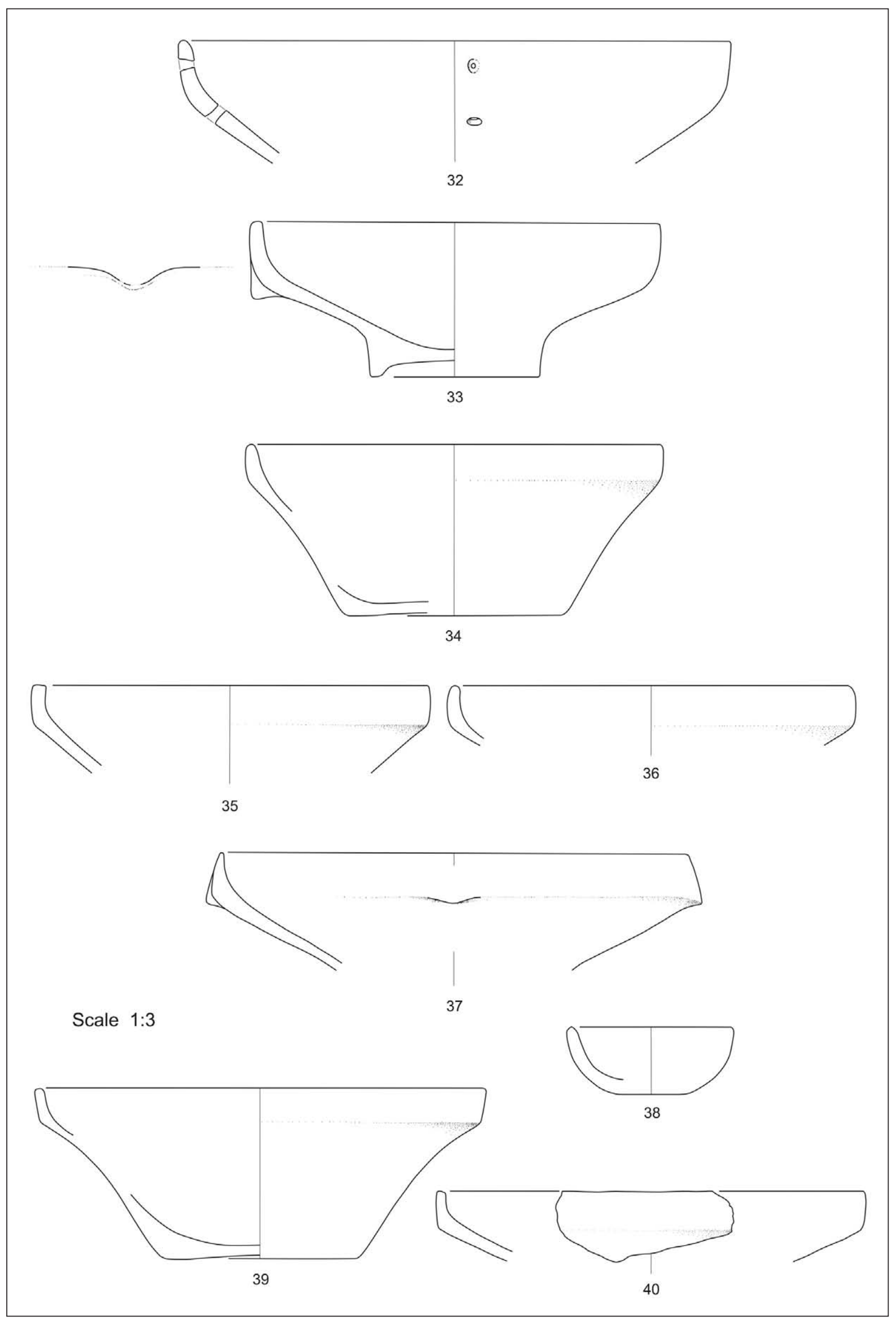

Pl. 6. Zgornje Radvanje, Cluster 10. Ceramic. SE 271. Phase 2. 

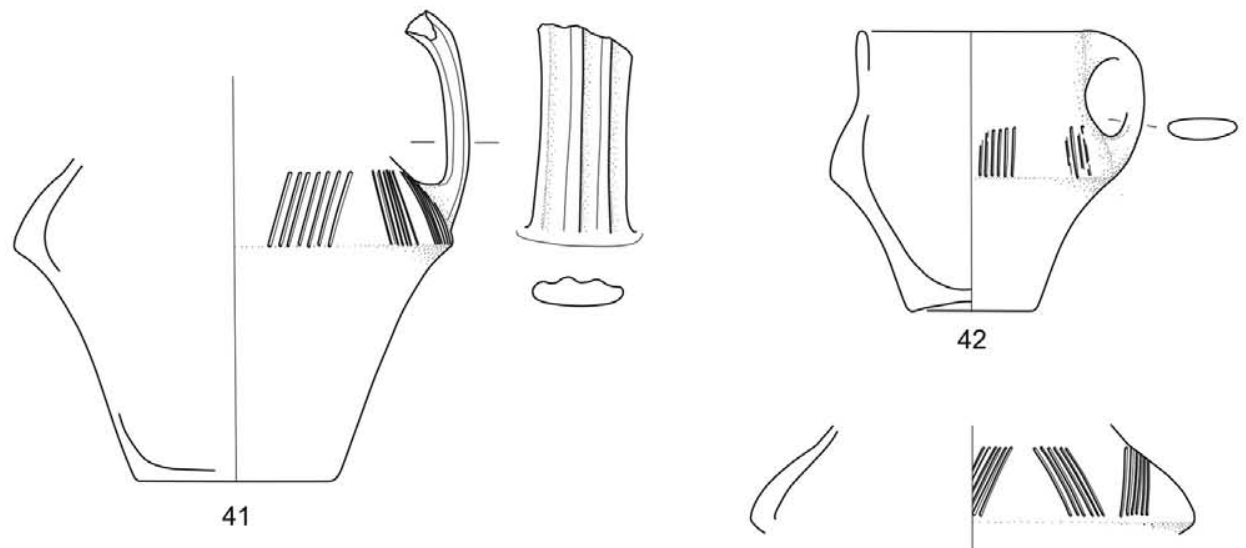

43
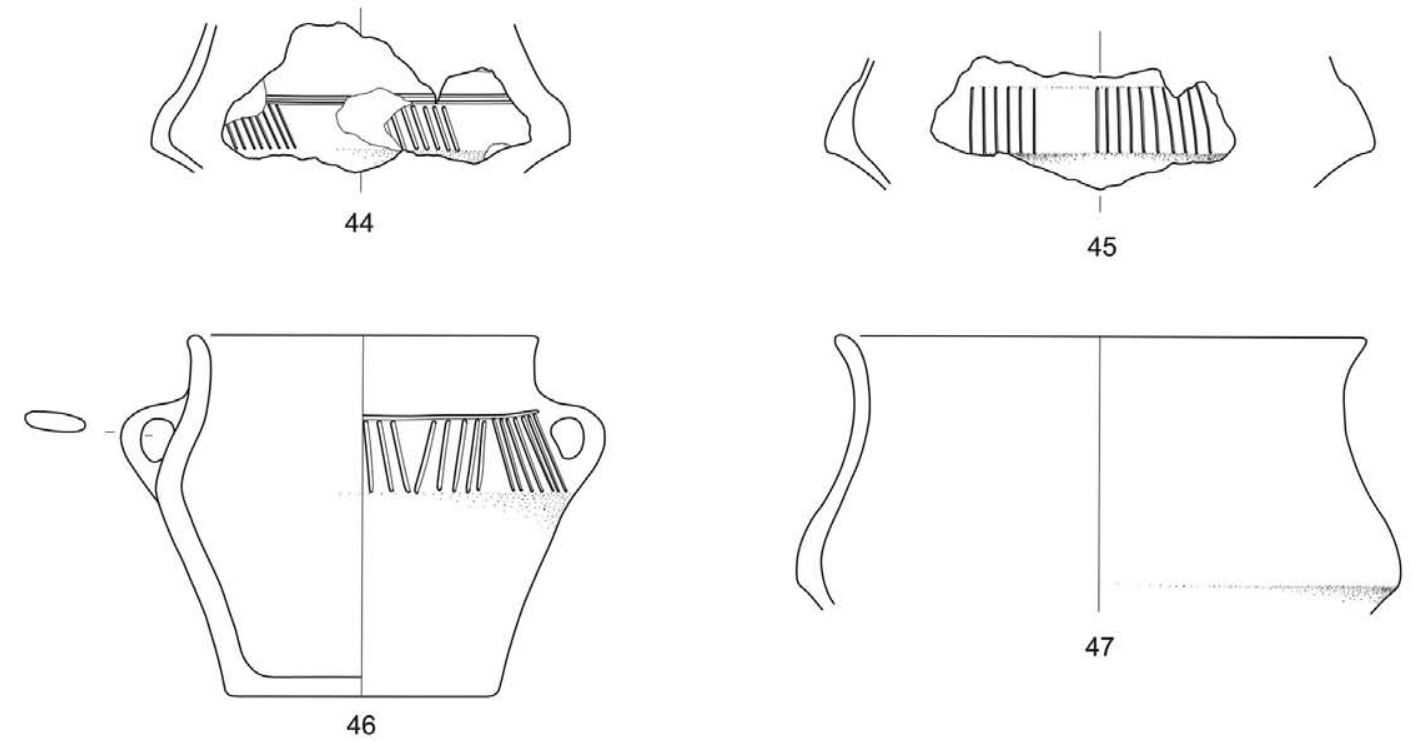

47

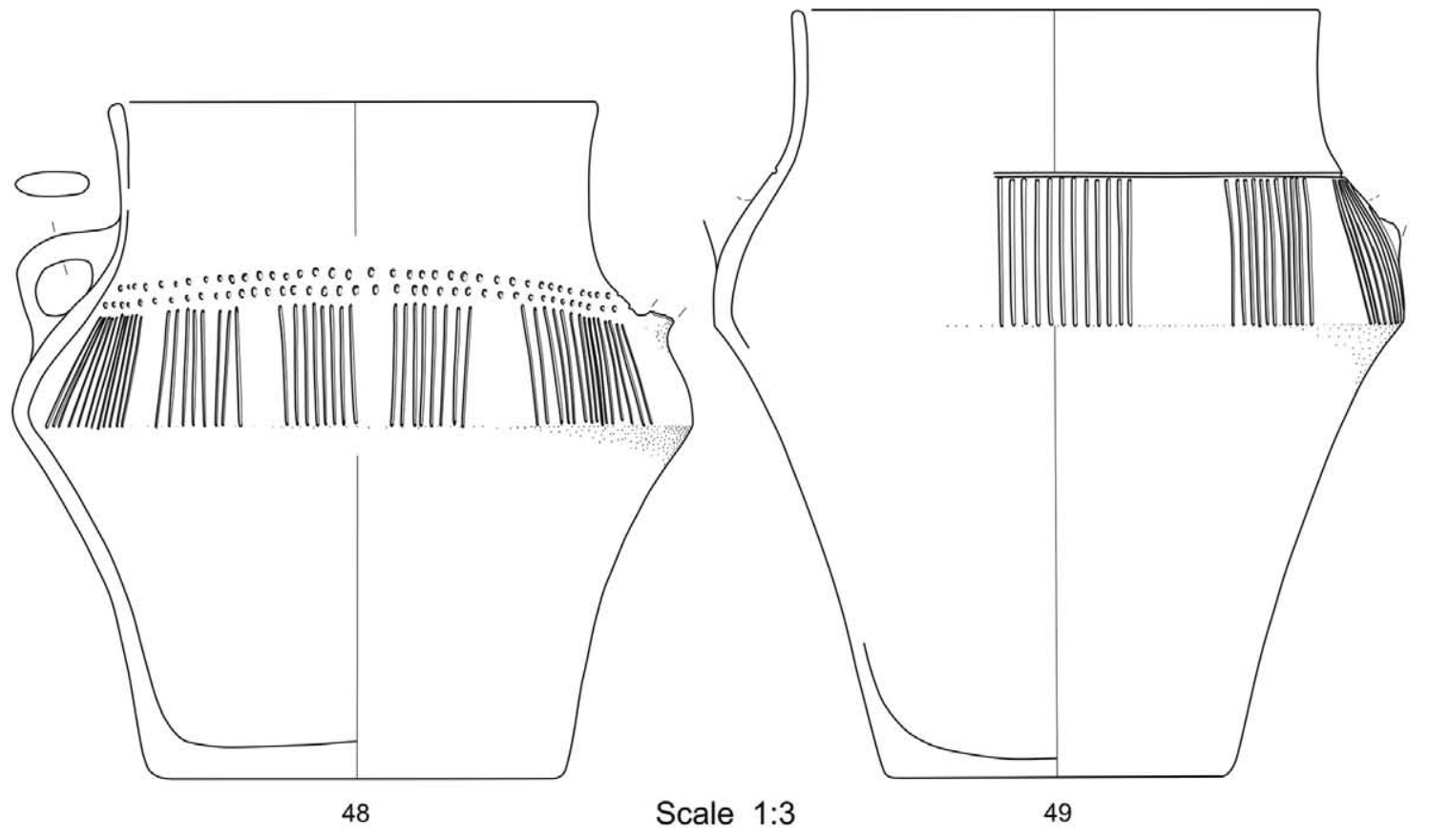

Pl. 7. Zgornje Radvanje, Cluster 10. Ceramic. SE 271. Phase 2. 

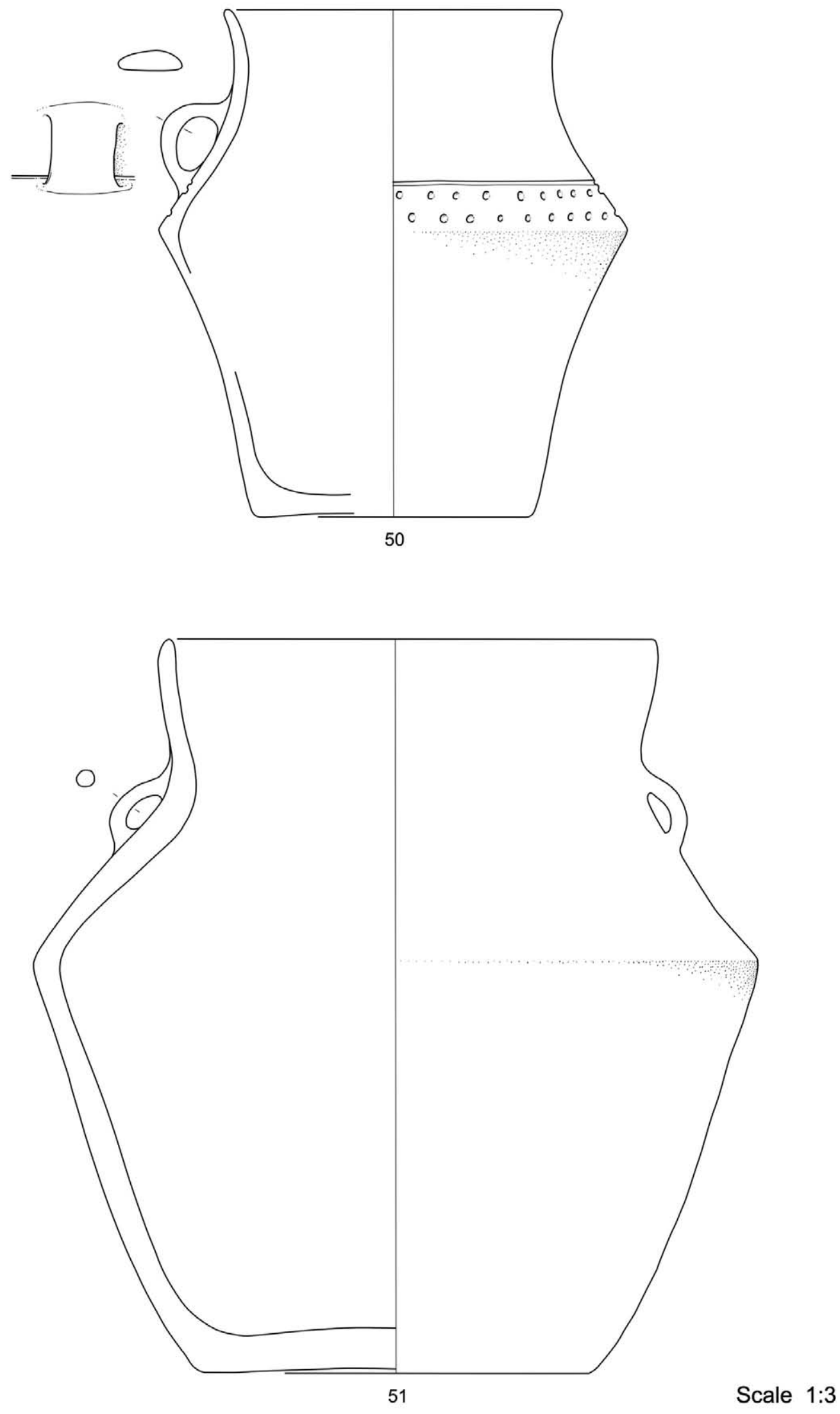

Pl. 8. Zgornje Radvanje, Cluster 10. Ceramic. SE 271. Phase 2. 


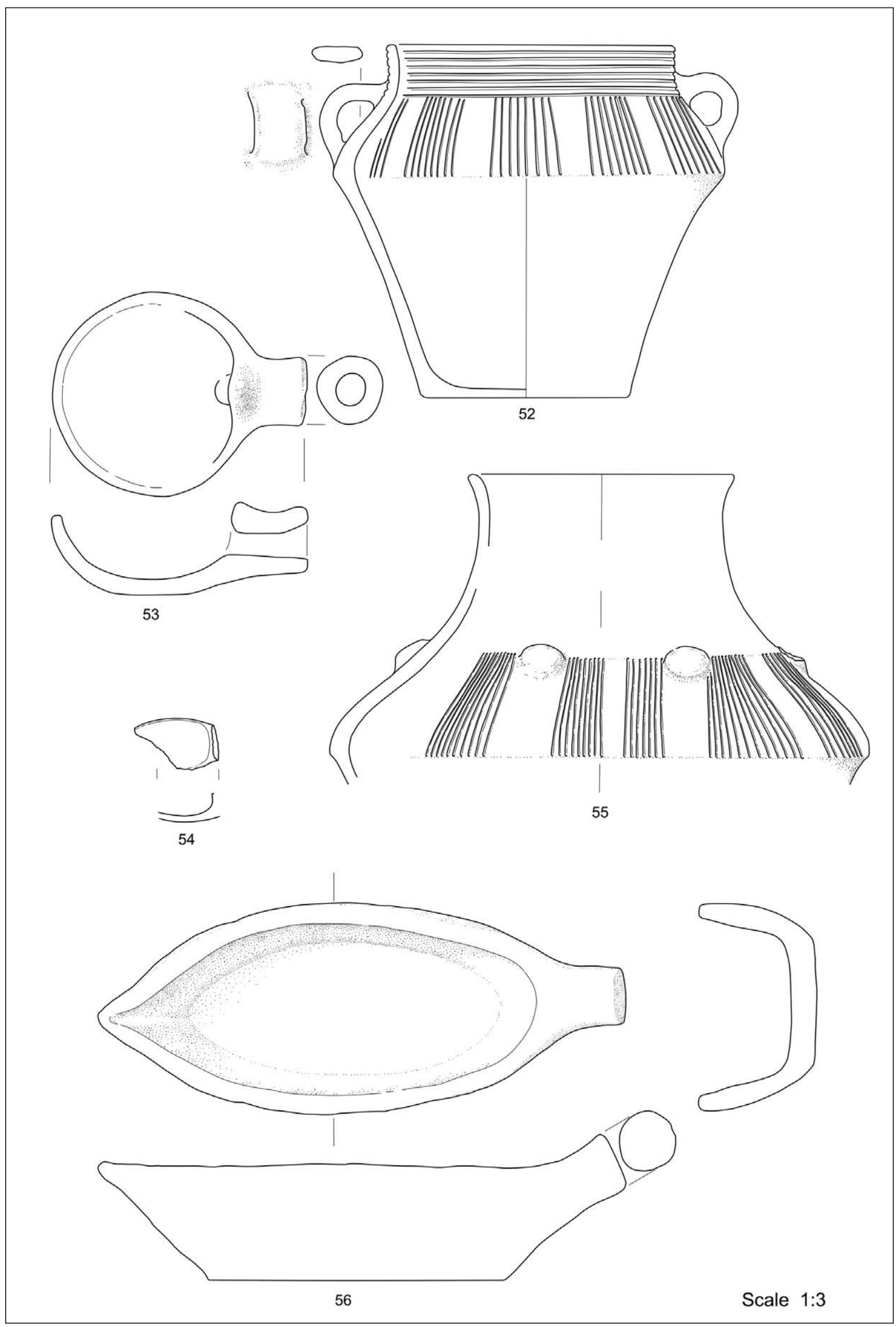

Pl. 9. Zgornje Radvanje, Cluster 10. Ceramic. SE 271. Phase 2. 


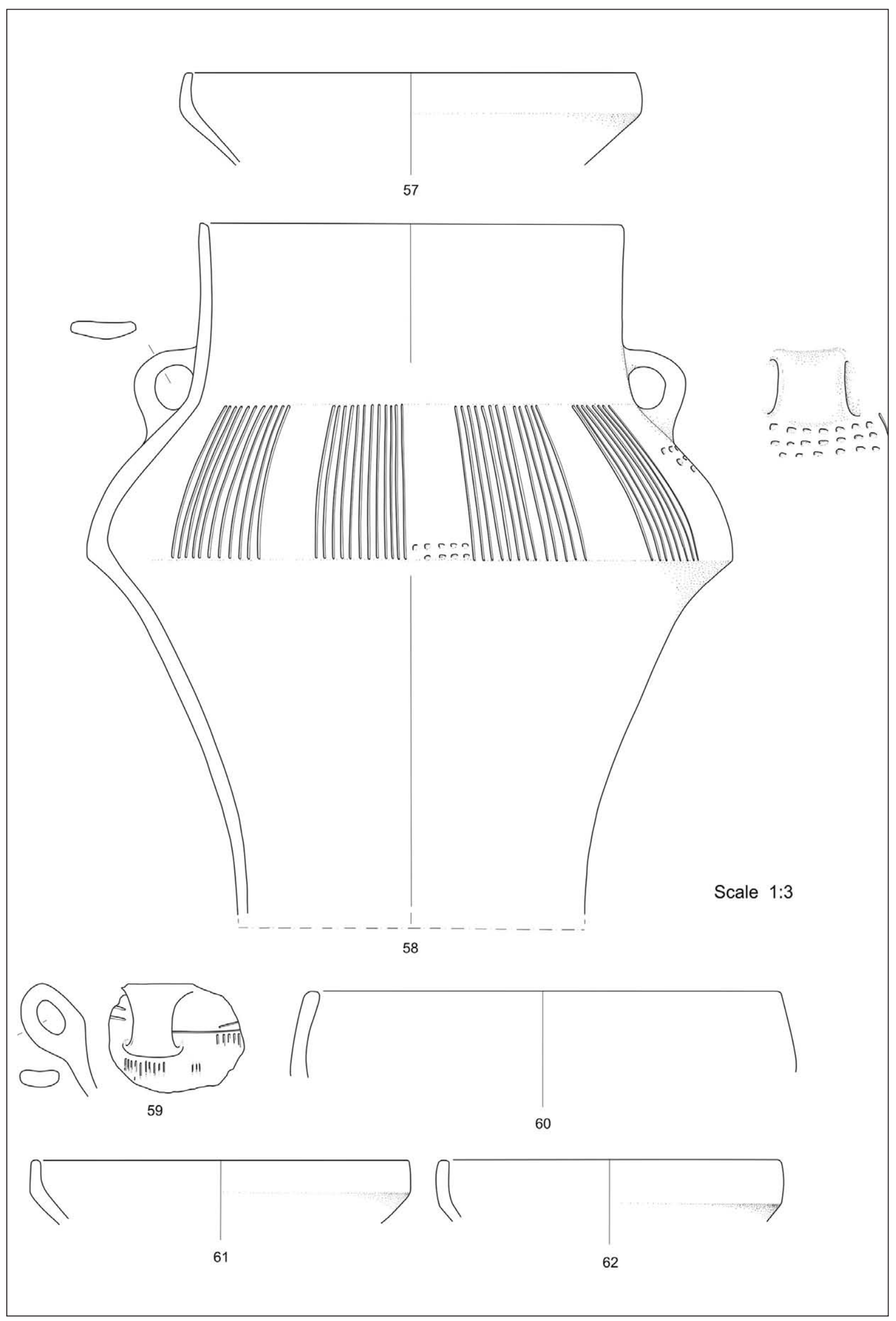

Pl. 10. Zgornje Radvanje, Cluster 10. Ceramic. SE 238 (57-58). Phase 2. SE 232 (59-62). Phase 4. 


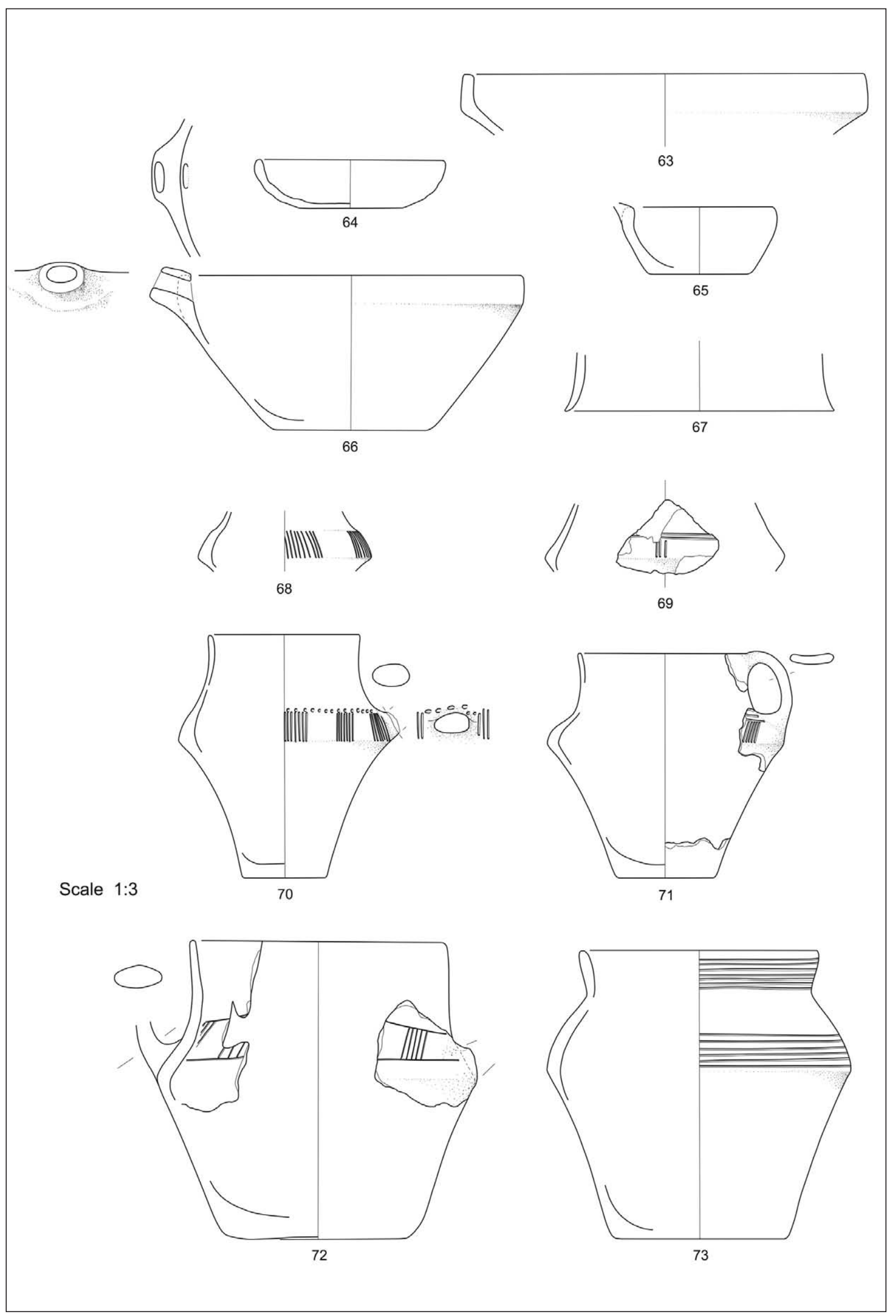

Pl. 11. Zgornje Radvanje, Cluster 10. Ceramic. SE 232. Phase 4. 


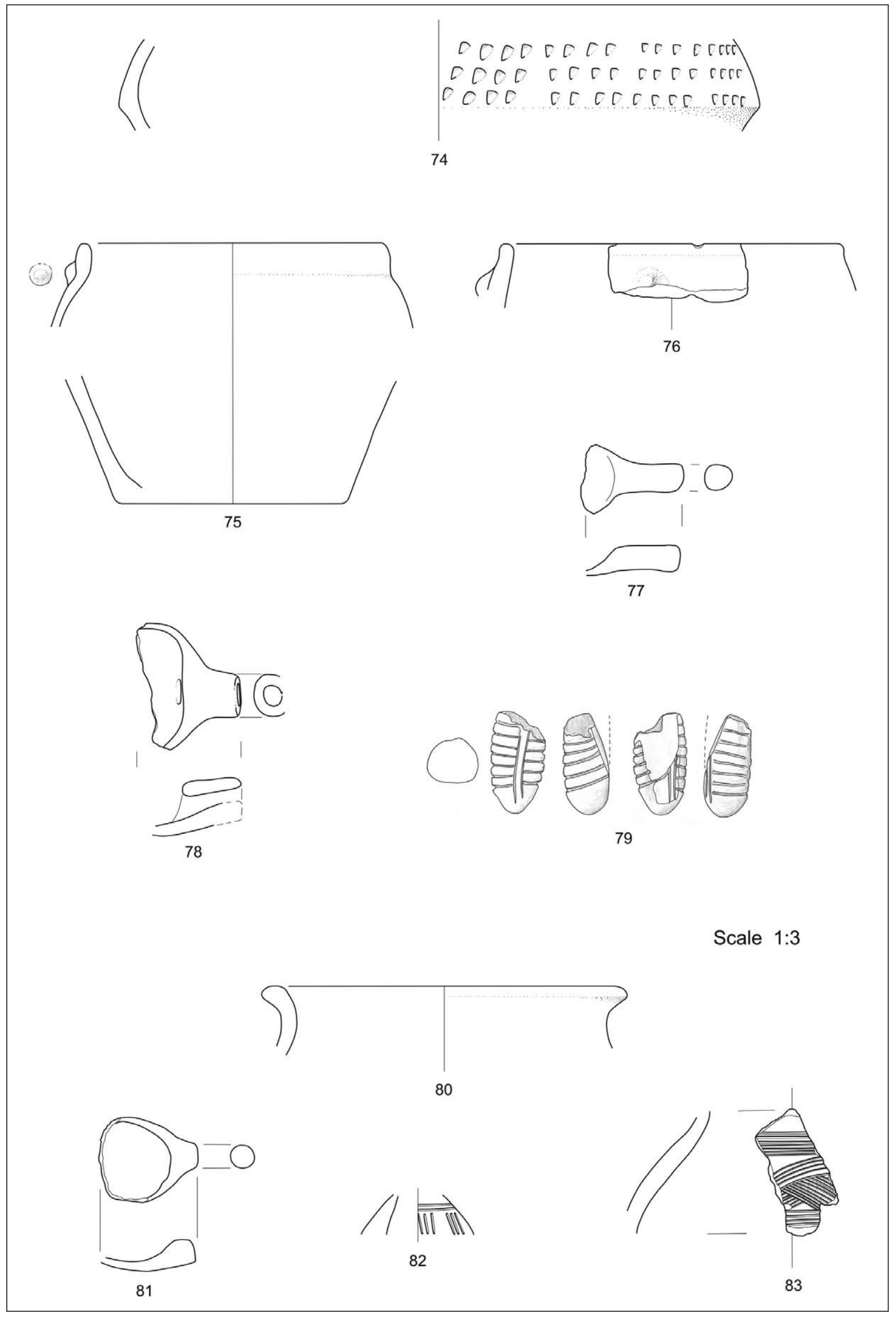

Pl. 12. Zgornje Radvanje, Cluster 10. Ceramic. SE 232 (74-79). Phase 4. SE 234 (80-83). Phase 5. 